\title{
Ultraviolet radiation shapes seaweed communities
}

\author{
Kai Bischof · Ivan Gómez • Markus Molis • \\ Dieter Hanelt • Ulf Karsten · Ulrike Lüder • \\ Michael Y. Roleda · Katharina Zacher · \\ Christian Wiencke
}

Received: 10 March 2006/ Accepted: 8 May 2006

(C) Springer Science+Business Media B.V. 2006

\begin{abstract}
Stratospheric ozone depletion and the concomitant increase in irradiance of ultraviolet-B radiation (UVB) at the earth's surface represent major threats to terrestrial and aquatic ecosystems. In costal rocky shore environments, seaweeds constitute a group of organisms of particular significance to ecosystem function. Thus, impairment of seaweed performance by UVB-exposure may result in severe changes in the functioning of coastal ecosystems. Here we present our view on
\end{abstract}

K. Bischof $(\bowtie)$

Institute for Polar Ecology, University of Kiel, Wischhofstr. 1-3, Building 12, 24148 Kiel, Germany e-mail: kbischof@ipoe.uni-kiel.de

\section{Gómez}

Instituto de Biologia Marina, Universidad Austral de Chile, Casilla 567, Valdivia, Chile

\section{Molis · M. Y. Roleda}

Alfred Wegener Institute for Polar and Marine Research, Marine Station, 27498 Helgoland, Germany

\section{Hanelt}

Biocenter Klein-Flottbek, University of Hamburg, 22609 Hamburg, Germany

\section{U. Karsten}

Institute of Biological Sciences, Applied Ecology,

University of Rostock, 18059 Rostock, Germany

U. Lüder $\cdot$ K. Zacher $\cdot$ C. Wiencke

Alfred Wegener Institute for Polar and Marine

Research, 27570 Bremerhaven, Germany how UVB radiation affects seaweed physiology and ecology and, thus, shapes the coastal environment by affecting the spatial, species and functional structure of seaweed communities.

Keywords Acclimation P Photosynthesis · Seaweeds · Ultraviolet radiation ·

Vertical zonation

\section{Introduction to seaweed communities}

Seaweeds (also referred to as "marine macroalgae") represent key components within coastal ecosystems (Lüning 1990). As primary producers these green, brown or red coloured marine plants serve a multitude of ecosystem functions. They may grow from just a few millimetres in size up to $60 \mathrm{~m}$ or even more. At their growth site they often form submersible forests (i.e., "kelp forests" in cold-temperate oceans) characterized by high primary productivity. For instance, along the coasts of cold-temperate regions, the communities dominated by the brown algal genus Laminaria have annual productivity rates of about $2 \mathrm{~kg}$ carbon per $\mathrm{m}^{2}$ (Thomas 2002). Seaweeds are globally distributed from the Tropics to the Polar Regions and primarily settle on hard bottom substrate, such as rocky shorelines. Here, seaweed communities typically show distinct vertical zonation patterns exhibiting a characteristic sequence of 
species with increasing depth (Stephenson and Stephenson 1972). Along with the depth gradient, the environmental parameters seaweeds are exposed to change drastically. Species settling in the supralittoral zone (the fringe above the high tide level) are exposed to drought, high solar radiation and also atmospheric changes in temperature. The intertidal fringe (the eulittoral zone) is moreover characterised by regular and extreme changes in abiotic conditions, based on tidal influence (Davison and Pearson 1996). During low tide, organisms are exposed to high solar irradiance, drought, atmospheric temperatures, and, depending on current weather conditions, sometimes extreme changes in salinity (Schonbeck and Norton 1978; Davison and Pearson 1996). Furthermore, mechanical stress due to tidal currents and wave exposure has a strong impact on intertidal communities. Underneath, in the sublittoral zone extending below the low tide level, seaweeds usually encounter a more stable habitat, as the water column above buffers against strong changes in abiotic parameters. As outlined below, it is also the respective characteristics of the water column, which determines exposure of sublittoral organisms towards UVB exposure.

Seaweeds interact with and play an existential role for many marine animals (Lubchenco and Gaines 1981; Hay and Fenical 1992). The most important functions of seaweeds in this context are the supply of food and habitat to and their effects on the recruitment and dispersal of animals. Being at the basis of marine food webs, seaweeds are directly consumed by a diversified suite of micro- and macrograzers, which in turn can alter structure and species composition of seaweed communities (Duffy and Hay 2000). In addition, algal exudates might fuel the microbial loop if they are used by free-living and algaassociated bacteria. However, algae can also adversely affect animals. For instance, decomposing algal mats produce anoxic conditions affecting survival of covered animals.

Seaweeds serve many species as habitat, to which sessile forms attach directly, and may host motile animals by provision of shelter from predators (Lippert et al. 2001). Open space is a key resource for sessile marine species and in this way, seaweeds ameliorate competition for space.
Seaweeds are also among the first multi-cellular colonizers and thus precondition the substratum for later successional recruits. Subsequent settlement of spores and larvae may be facilitated, tolerated, or inhibited in dependency of the already existing seaweed community (Sousa and Connell 1992). Furthermore, larger seaweeds serve as eggdeposition sites of predatory fin and shell fish, thereby supporting indirectly top-down control in coastal habitats. Furthermore, dislodged seaweeds serve as dispersal vectors for species, accelerating the transport of invasive species and the recolonisation of defaunated habitats (Thiel and Gutow 2005).

Due to their enormous importance within coastal ecosystems a decrease in seaweed abundance related to environmental change e.g., under increased UVB irradiance will thus have dramatic consequences for the sum of organisms associated. Even under the present radiation conditions, UVB represents a crucial environmental factor organisms have to deal with. The knowledge on the physiological and ecological effects of present UVB irradiances is a precondition in order to be able to estimate future consequences of ozone depletion and increased UVB levels. Thus, in the following we present our view on how UVB radiation may shape seaweed dominated coastal ecosystems under the present radiation conditions and how the spatial and functional structure of seaweed communities might be affected in the future.

\section{Enhanced UVB radiation}

Solar radiation is the most important prerequisite for life on earth. In the process of photosynthesis, photoautotrophic organisms (like seaweeds) convert light energy into chemically bound energy, which is used for biomass production; as a side effect, molecular oxygen is generated as a basis for all heterotrophic organisms. Changes in irradiance and light quality can either promote photosynthesis, but can also inhibit many biological processes if radiation becomes excessive (Barber and Andersson 1992), or if short wavelength radiation with high energy content, such as UVB radiation, is absorbed by 
biomolecules (Vass 1997). Consequently, damage to important components in plant metabolism results in reduced photosynthetic and general metabolic activity and, hence, lead to a decrease in biomass production.

Ever since the discovery of stratospheric ozone depletion in the Antarctic in the 1970s (Farman et al. 1985), serious concerns have arisen about the impacts of increasing UVB radiation on the biosphere (Madronich et al. 1998; Björn et al. 1999). Ozone is predominantly generated in the low latitudes, by photolysis of molecular oxygen. In the stratosphere, ozone molecules are subject to UV-mediated photolysis and may also be degraded due to the reaction within catalytic cycles with $\mathrm{NO}, \mathrm{Cl}$ or Br serving as catalysts (Lary 1997; Langer 1999). The concentration of these compounds in the atmosphere increases mainly due to anthropogenic emissions, thus leading to ozone depletion.

Ultraviolet radiation includes the wavelengths below those visible to the human eye. This spectral range is according to the CIE definition (Commission Internationale de l'Eclairage 1935) divided into three wavebands: $315-400 \mathrm{~nm}$ UVA, 280-315 nm UVB, and 190-280 nm UVC, which does not reach the earth's surface, as it is completely absorbed on its way through the atmosphere. Due to the optical characteristics of ozone, it is the UVB range, which is likely to increase at the earth's surface, as a consequence of a decrease in stratospheric ozone concentration. Calculations based on the absorption characteristics of $\mathrm{O}_{3}$ indicate that a $10 \%$ decline in column ozone would result in an approx. $5 \%$ increase of surface irradiance at $320 \mathrm{~nm}$ while the same decline would be accompanied by a $100 \%$ increase at $300 \mathrm{~nm}$ (Frederick et al. 1989).

\section{UVB in the aquatic environment}

The effects of UVB on aquatic ecosystems are strongly dependent on the optical properties of the water body (Holm-Hansen et al. 1993; Hanelt et al. 2001). Therefore, it is necessary to estimate the penetration of UV radiation into the water column. The UV irradiance reaching the water surface is influenced by various atmospheric factors, such as latitude and altitude, elevation of the sun coinciding to the season and the time of day, weather conditions (clouds and fog), ozone and aerosol concentrations. The underwater light field is even more variable: In coastal sea waters, UV radiation and blue light are strongly attenuated due to dissolved organic matter (DOM; Kirk 1994), and this depends largely on the input of this material from the terrestrial ecosystem. According to Kirk (1994), the diffuse vertical attenuation coefficient of downward irradiance $\left(K_{\mathrm{d}}\right)$ in the water column is determined by the following formula:

$K_{\mathrm{d}}=\ln \left(\operatorname{Ed}_{\left(z_{2}\right)} / \operatorname{Ed}_{\left(z_{1}\right)}\right)^{*}\left(z_{1}-z_{2}\right)^{-1}$

with $\operatorname{Ed}_{\left(z_{1}\right)}$ and $\operatorname{Ed}_{\left(z_{2}\right)}$ as the respective irradiance in depth $z_{1}$ and $z_{2}$. The value of the $K_{\mathrm{d}}$ in the UVwaveband is naturally much higher than for the PAR range (Jerlov 1976) and typically increases tremendously during the summer season in polar coastal waters (Hanelt et al. 2001). The reason is that the turbidity of the coastal water in polar regions rises due to rainfall or melt water from snow layers and glaciers. A high discharge of turbid fresh water into the coastal zone carries fine terrigenous sediments into the seawater (Svendsen et al. 2002). In the Arctic the variation in $K_{\mathrm{d}^{-}}$ values showed that from middle of June, UVB transparency decreased strongly due to the input of turbid melt waters on Spitsbergen (Hanelt et al. 2001) or in the Hudson bay (Vincent and Belzile 2003). While the UVB transmittance decreased only by about $22 \%$ per meter in clear waters during spring, the attenuation increased to about $53 \%$ per meter in summer, so that UVB was almost fully absorbed within the first $3 \mathrm{~m}$ of the water body at Spitsbergen. In spring and late autumn at low air temperatures the water conditions are relatively clear. Then, UV radiation penetrates deeply into the water column and the threshold irradiance of UVB with the potential to affect primary plant productivity negatively is still at about 5-6 m depth. In contrast to the situation in sheltered bays and fjords, at open coastlines with strong current, melt water can be replaced much faster with clearer oceanic water, which diminishes the observed turbidity effects on light penetration. Climate-induced changes in planktonic or 
allochthonous sources of DOM, either through changes in vegetation cover, decomposition, or glacial meltwater may have a higher impact on the underwater UVB regime than ozone depletion would produce (Franklin et al. 2003). Vincent and Belzile (2003) found a close correlation between UV attenuation and seston concentration in the Antarctic region. In the south western Ross Sea a high particulate absorption in the UVB waveband was observed during a phytoplankton bloom which was rather caused by the absorption of chromophoric dissolved organic matter (Arrigo and Brown 1996). Arctic and Antarctic Oceans both experience increased biological UV exposure resulting from stratospheric ozone depletion. However, climate related sea ice melting in the Arctic may potentially result in greater change in underwater UVB exposure than the increase caused by recent ozone depletion in Antarctica (Vincent and Belzile 2003). In summary, the respective optical characteristics of the water column determine the under water light climate and thus also UVB absorption in the aquatic environment. As UVB exposure is decreasing with increasing depth, the attenuation of UV radiation in the water column represents a major structuring frame for seaweed communities.

\section{Biological effects of UVB}

The effects of UVB exposure on biological systems are manifold, and reach from the molecular to the organism level, thereby affecting growth and production, and, consequently, ecosystem structure and function. A prerequisite for UVB induced damage is the absorption by biomolecules. Potential UV-chromophores in plants mainly include nucleic acids (such as DNA, RNA) and proteins (Vass 1997). DNA is one of the most UV-sensitive molecules and UVinduced damage occurs directly by the absorption of UVB quanta by aromatic residues. The results are direct structural alterations such as formation of cyclobutane dimers (Lois and Buchanan 1994), but can also be indirectly mediated due to the presence of free oxygen radicals, generated by the electron transfer from chromophore molecules, excited by UV absorption (Mitchell and Karentz
1993). UV-induced damage to the DNA represents a serious effect, as photoproducts can inhibit replication or even cause mutations, thereby affecting gene expression. UVB absorbing aromatic residues are also present in certain amino acids (e.g., tyrosine, phenylalanine, tryptophan) and, therefore, in proteins. Consequently, damage to protein molecules is a major effect of UVB in organisms. Furthermore, disulphide bonds between cysteine residues in the protein can be cleaved by UVB radiation (Vass 1997). These bonds have an important role in protein folding, and thus, are essential for proper functioning of the protein. Lipids, a major compound in all biological membranes, may be destroyed by UVB in the presence of oxygen. This peroxidation of unsaturated fatty acids has a direct effect on membrane structure and the generation of lipid peroxy radicals can induce further damage by participating in free radical cascades (Murphy 1983). In plants, pigments of the photosynthetic apparatus can also be destroyed by UV exposure (Strid et al. 1990), with the phycobilins being the most sensitive, and carotenoids generally being less affected than the chlorophylls (Teramura 1983; Häder and Häder 1989). As a consequence of a number of molecular effects, several physiological processes are impaired, such as photosynthesis (Bornman 1989; Strid et al. 1990; Nogues and Baker 1995; Allen et al. 1997), and nutrient uptake (Döhler 1985, 1992; Flores-Moya et al. 1998; Gómez et al. 1998), while others, e.g., respiration, appear to be less affected (Larkum and Wood 1993; Aguilera et al. 1999).

Photosynthesis is probably the most intensively studied process in plant biology. Due to its central role in plant metabolism, as well as its importance for all oxygen dependent life on earth, studies on adverse effects on photosynthesis, in the context of a globally changing environment are of particular interest. Due to numerous effects of UVB radiation to the respective molecules involved in photosynthesis, the effects of UV-exposure are also multiple (see Vass 1997 for review). The common consequences on photosynthetic function are decreased $\mathrm{CO}_{2}$-fixation and oxygen evolution (Renger et al. 1986; Allen et al. 1997). This could be caused by several molecular events: While most studies have found that photosystem I (PS I) is only 
minimally affected by UVB (by inhibiting PS I-mediated cyclic photophosphorylation; Iwanzik et al. 1983; Renger et al. 1986), photosystem II (PS II) seems to be a more important target (Bornman 1989). It is likely that UVB causes an inhibition of energy transfer within the PS II reaction centre by blocking electron flow. Furthermore, the function of the $\mathrm{D}_{1}$ protein may be impaired by the UVB induced fragmentation of the protein (Renger et al. 1986; Vass 1997). On the oxidising side of PS II, the oxygen evolving system (water splitting complex) is another sensitive target of UVB (Renger et al. 1986). Furthermore, it has been suggested that UVB may affect the light-harvesting complex (LHC) by its functional disconnection from the photosystem, resulting in an impairment of energy transfer to the reaction centre (Renger et al. 1986; Lorenz et al. 1997). A decrease in photosynthetic activity may also be due to the photodestruction of pigments; within the chlorophylls, Chl $a$ has been observed to be more affected than Chl $b$ (Teramura 1983; Strid et al. 1990).

The $\mathrm{CO}_{2}$ fixing enzyme RubisCO has been shown to be another critical component in UVBinduced inhibition of photosynthesis. The UVBinduced decline in its activity is related to the decreasing amount of both subunits as well as the corresponding mRNA levels (Strid et al. 1990; Jordan et al. 1992; Bischof et al. 2000a, 2002a). Another effect of UVB on reactions related to photosynthesis represents the inactivation of chloroplast ATPase (Strid et al. 1990). Impairment of any of the components mentioned above contributes to lower the photosynthetic activity during and following UV-exposure.

The physiological effects are also reflected on the ultrastructural level. UVB radiation can lead to dramatic changes of the fine structure of chloroplasts and mitochondria. Mild UV stress leads to a wrinkled appearance of the thylakoids, lumen dilatations and damage of the outer membranes. In the mitochondria a swelling of the cristae is often observed (Poppe et al. 2003; Holzinger et al. 2004). After strong UVB exposure the formation of 'inside-out' vesicles from thylakoids was demonstrated in four red algal species. In Palmaria decipiens the fine structural changes are reversible indicating acclimation to UV stress (Poppe et al. 2002, 2003).
On the organism level, the effects mentioned above can result in reduced growth and production, as shown in higher plants, seaweeds, phytoplankton and ice algae (Caldwell 1971; Worrest 1983; Ekelund 1990; Karentz et al. 1991a, b; Holm-Hansen 1993; McMinn et al. 1999, Han 1996a, b; Makarov 1999; Aguilera et al. 2000; Altamirano et al. 2000a, b). Other effects include the impairment of reproductive success or may even bear lethal consequences. Consequently, all aspects mentioned may also affect ecosystem structures (Holm-Hansen et al. 1993; Johanson et al. 1995; Caldwell et al. 1998).

\section{Seaweed responses to UVB}

Seaweeds became a prominent group of organisms in UVB research for two reasons. Firstly, seaweeds represent a crucial component for coastal ecosystems. Thus, UVB related damage to these organisms might have drastic consequences to the entire ecosystem. Secondly, in a range of field and laboratory studies, seaweeds were proven to be in general rather sensitive to UVB exposure (at least compared to terrestrial plants) but also it was shown in some species growing over a wide depth or even geographical range, that seaweeds do apply a vast variety of acclimation mechanisms. Thus they became very suitable model systems also in basic stress physiology.

\section{Adaptation versus acclimation}

The respective reaction of a species towards UVB exposure is determined by the interplay of genetically fixed adaptation and physiological acclimation. Generally spoken, adaptation is setting the frame in which acclimation to changing environmental conditions might occur.

In a laboratory study on Antarctic seaweeds, which were isolated in the field decades ago and subsequently kept in stock cultures it was shown that these specimens still exhibit distinct speciesspecific differences in UV-tolerance once they are grown to macrothalli and exposed to identical culture and experimental UV conditions (Bischof et al. 1998a). Due to the cultivation of sporophytes under low-light conditions and UV-exclusion 
no acclimation to UV radiation had occurred prior to the experiments. The two shallow-water green algae Enteromorpha bulbosa and Acrosiphonia arcta were least affected by UVB radiation. Photosynthesis in the brown algae Desmarestia antarctica and D. anceps and the red alga Gymnogongrus antarcticus, inhabiting slightly deeper waters, was inhibited to a similar and intermediate extent. However, two other red algal species from the lower subtidal, Phycodrys austrogeorgica and Delesseria lancifolia, responded extremely sensitively towards UVBexposure. In the case of Delesseria sanguinea, a deep sublittoral species, growth can be also strongly impaired when the alga is exposed to surface solar radiation (Pang et al. 2001) indicating these plants may lack all protecting mechanisms against excessive radiation. In the field protective mechanisms against UV radiation might not be necessary because they live in the shade of the canopy algae and/or in great depths. Similarly, zoospores of the deep-water species L. saccharina and L. hyperborea are more strongly photoinhibited after exposure to UV radiation than zoospores from the shallow water species L. digitata (Roleda et al. 2005a). In addition, recovery of PS II activity is high in $L$. digitata, low in L. saccharina and lowest in L. hyperborea. Spores of the eulittoral M. stellatus and $C$. crispus are photoinhibited after UV exposure but recover quickly after exposure to dim white light (Bischof et al. 2000b; Roleda et al. 2004). The first attempt to study kinetics of photoinhibition and recovery in zoospores of Arctic Laminariales showed that zoospores of the lower sublittoral L. saccharina were more sensitive to PAR- and UV-induced photoinhibition than upper- to midsublittoral $S$. dermatodea, $A$. esculenta and $L$. digitata. Kinetics of recovery in zoospores showed a fast phase in S. dermatodea which indicates a reduction of the photoprotective process while a slow phase in L. saccharina indicates recovery from severe photodamage (Roleda et al. 2006d). These experiments were focussed on short-term effects, thus the preadaptive setting of species could be revealed, but not the respective potential of acclimation, also determined by the genetic features of species.
In another study, six different red algal species from cold-temperate regions and with different zonation patterns were cultivated under identical culture conditions and exposed to similar irradiance of UVB (van de Poll et al. 2001). The inhibition of growth became stronger in accordance with the position on the shore these algae usually take in the field. The two species from the upper sublittoral or even lower eulittoral zone (Palmaria palmata and Chondrus crispus) did hardly exhibit inhibition in growth, whereas growth in the species from the middle sublittoral zone (Phyllophora pseudoceranoides and Rhodymenia pseudopalmata) was inhibited up to $50 \%$. In the deep-water algae Phycodrys rubens and Polyneura hilliae, growth was inhibited almost completely. Curiously, pronounced accumulation of damaged DNA, expressed as thymine dimer formation, was only found in these two species. Apparently these true deep-water algae do lack mechanisms to shield the DNA from UVB exposure or to repair already damaged DNA e.g., by the activity of repair-enzymes (as e.g., DNA phytolyase). This study illustrates how genetic pre-adaptation is setting the frame in which acclimation may occur. The fact that not any acclimation to UVB was shown by these species points to a strong degree of adaptation to low irradiance environments.

Modulation of ecophysiological reactions towards variation in abiotic factors is conditioned by genetic adaptation. This is also visible in two red algal species from Spitsbergen with slightly different vertical zonation preferences (Karsten et al. 1999). Devaleraea ramentacea as a species from shallow waters is permanently equipped with high activities of reactive oxygen scavenging superoxide dismutase (SOD). This high but static activity is reasonable for a species from shallow waters, where usually strong variation in abiotic conditions, and thus the onset of stressfull conditions to photosynthesis resulting in increased ROS production, is more likely than in more stable deeper waters. However, maintaining a protective systems on such a high level throughout the year is probably energetically costly. Thus, species which are not permanently exposed to stressfull conditions, e.g., in deeper waters, may favour the 
strategy to respond to abiotic stress and to increase protective strategies, like SOD activity, only when they are needed during times of e.g. high UV irradiance. Palmaria palmata inhabiting slightly deeper waters than $D$. ramentacea is applying this strategy (Karsten et al. 1999). In the case of the estuarine red alga Gracilaria chilensis, which is subject to extremely changing light conditions both during tidal cycles and seasonally, exposures to surface UVB irradiances induce marked reductions in photosynthesis (Gómez et al. 2005a). Although the species can display rapid acclimation mechanisms, the constitutively high pigment contents and low concentrations of sunscreen substances (e.g., MAAs), clearly suggest that the Gracilaria retains its shade adapted characteristics, probably as a consequence of the normally turbid waters at the estuary.

\section{Acclimation of photosynthesis to $U V$ radiation}

In seaweed species inhabiting a flexible environment, i.e., the shallow water zones down to approx. $15 \mathrm{~m}$ depth, acclimation to changing abiotic conditions is important, to adjust photosynthetic performance in order to maintain energy supply for growth, but also to prevail under periods of stressfull conditions. The ability for fast acclimation to increased UV irradiance has been demonstrated in the Arctic/cold-temperate kelp Alaria esculenta from Spitsbergen (Bischof et al. 1999). It was shown that its macrothalli are able to adjust photosynthetic performance to changes in irradiance at their respective growth site. This capability may represent one prerequisite for this species to establish over a wide depth range and also to endure the seasonal variation of radiation conditions (Chapman and Lindley 1980; Falkowski and LaRoche 1991; Klöser et al. 1996; Bischof et al. 1998b, 1999).

Within the brown algae studied so far, two different responses were observed in the process of acclimation of photosynthetic activity to changing radiation conditions. Firstly, the rate of recovery from UV-induced photoinhibition increases. Secondly, the degree of inhibition becomes smaller (Bischof et al. 1998b, 1999). Increases in the rate of recovery may result from an activation of different repair mechanisms, counteracting the impact of UV-exposure by a faster replacement of damaged molecules. The molecular mechanism responsible may be the same as discovered in the cyanobacteria Synechocystis sp. and Synechococcus sp. In both species, it was found that exposure to moderate doses of UVB results in an increased turnover rate of the $D_{1}$ and $D_{2}$ reaction centre subunits of PS II, thus, rapidly replacing damaged protein by newly synthesised polypeptides (Campbell et al. 1998; Máté et al. 1998). The latter authors found that UVB induces the transcription of psbA genes, which encode the $\mathrm{D}_{1}$ reaction centre protein of PS II. Although comparable studies are lacking for macroalgae, it may be that a similar response provides an explanation for the increasing rate of recovery in the studied brown algal species. However, this mechanism may only be successful as long as UVB exposure does not induce stronger damage to DNA, thus impairing gene expression. Results also showed, that in algae previously acclimated to high PAR, additional UV-exposure rather results in a delay of the recovery process than in a further inhibition of photosynthesis (Bischof et al. 1999). These findings support data from field experiments on Fucus distichus from Spitsbergen, indicating that at their natural growth site in the eulittoral zone photoinhibition is mainly caused by high irradiances of PAR and natural UVB causing a delay in recovery (Hanelt et al. 1997a). The observed delay in recovery is indicative for damage to the $\mathrm{D}_{1}$ protein (Aro et al. 1993). Under UVB exclusion the rate of $D_{1}$ degradation mediated by solar radiation was found to be as much as $30 \%$ slower than under full sunlight (Greenberg et al. 1989), thus supporting those results for high light acclimated algae.

In contrast to subtidal species, intertidal brown algae, have to cope with highly changing solar radiation scenarios on a short term basis. In this sense, high PAR irradiances become as ecological important as UV radiation. Flores-Moya et al. (1999) observed a significant delay in recovery from photoinhibition in the brown alga Dictyota dichotoma from Southern Spain, when samples were exposed to solar radiation depleted from the UVB range and subsequently transferred to dim light conditions. Recovery in samples receiving 
either the whole solar spectrum or PAR only, recovered at the same rate. This indicates the presence of complex synergistic effects involved in the inhibition of photosynthesis in the field, which need to be studied further. On the other hand, it must be emphasized that brown algae include many large, perennial species, which exhibit complex responses to UV-exposure. For example, in the southern kelp Lessonia nigrescens, the photosynthetic responses to seasonally changing UV conditions form part of the suite of adaptations along with its ontogenic development, i.e., the alga has a complex UVB exposure history characterized by high levels of UVB in summer and low levels in winter (Huovinen et al. 2006). Moreover, gradients in UV tolerance have been reported along of the massive thallus (Gómez et al. 2005b). Thus, the morpho-functional factors involved in UV photobiology of brown algae are important and have to be considered in further studies in order to evaluate more accurately the effects of enhanced UVB on coastal primary productivity.

A common response observed in the brown algal species during acclimation to UV radiation is the reduction in the degree of photoinhibition. This effect may be explained either by the activation of the antioxidative response, increased activity of repair and recovery mechanisms counteracting the inhibitory effects (see above), or by the formation of UV-screening compounds (Lesser 1996).

\section{Mycosporine-like amino acids (MAA)}

One of the most important physiochemical acclimation mechanism against biologically harmful UV radiation involves the biosynthesis and accumulation of UV-screening substances. Typically absorbing in the UVA and UVB range, these biomolecules were invoked to function as passive shielding solutes by dissipating the absorbed short wavelength radiation energy in form of harmless heat without generating photochemical reactions (Bandaranayake 1998). The most common photoprotective sunscreens in Antarctic macroalgae are the mycosporine-like amino acids (MAAs), a suite of chemically closely related, colourless, water-soluble, polar and at cellular $\mathrm{pH}$ uncharged or zwitterionic amino acid derivatives. MAAs exhibit a high molar absorptivity for UVA and UVB, and have been reported as photochemically stable molecules, which are prerequisites for their sunscreen function (Conde et al. 2000). While MAAs have been mainly observed in numerous Antarctic (Karentz et al. 1991a; Hoyer et al. 2001) and cold-temperate Rhodophyta (Huovinen et al. 2004), Phaeophyta and most Chlorophyta typically lack these compounds, except the green alga Prasiola crispa ssp. antarctica which contains high concentrations of an unique MAA with an absorption maximum at $324 \mathrm{~nm}$ (Hoyer et al. 2001; Karsten et al. 2005). Many Phaeophyta synthesise photoprotective phlorotannins under UV exposure (Pavia et al. 1997; Schoenwaelder 2002b; Schoenwaelder et al. 2003), this strategy will be reviewed in detail below.

The function of MAAs as intracellular screening agents has been inferred from a decrease in concentration with increasing depth (Hoyer et al. 2001, 2003). Supra- and eulittoral Antarctic red algal species experience the strongest insolation, and consequently synthesise and accumulate very high MAA contents, which generally are positively correlated with the natural UV doses (Karsten et al. 1998a; Huovinen et al. 2004). In contrast, many taxa growing in the sublittoral are physiologically not capable to produce MAAs, which well explains their strong sensitivity, for example, of photosynthesis against ambient solar radiation. These Rhodophyta avoid any UV exposure, and, hence, there is no physiological need to synthesise and accumulate metabolically expensive nitrogencontaining MAAs. This in turn would save energy to better support other essential pathways such as light-harvesting phycobilisomes to guarantee sufficient PAR absorption under the prevailing low-light conditions.

While juvenile lateral fronds of the red alga Palmaria decipiens collected in Antarctic winter contained low concentrations of UV-absorbing compounds, mature plants in late spring and summer exhibited significantly higher values indicating strong seasonal effects (Post and Larkum 1993), which may be related to the changing daylengths and radiation conditions. Based on the MAA concentrations and the 
induction patterns after exposure to different radiation conditions Antarctic Rhodophyta can be physiologically classified in 3 categories (Hoyer et al. 2001): Type I-no MAAs at all; Type II-MAAs inducible in variable concentrations, and Type III-permanently high MAA values. While Type I represents deep-water red algae, Type II and III species are growing in the supra- and eulittoral zone. Experiments with Antarctic Rhodophyta under defined radiation sources indicate that the induction, biosynthesis and accumulation of MAAs is a very flexible and species-specific process. While some taxa synthesise MAAs particularly under UVB, others prefer UVA or higher PAR only (Hoyer et al. 2003). Although experimental evidence for a particular trigger mechanism as well as details for the biosynthetic pathway for individual MAAs are still missing, it is reasonable to assume that a signal transduction pathway must be involved in the overall process leading to high MAA concentrations. Due to the different types of MAA induction patterns the presence of various photoreceptors, most probably between the blue light and UVB wavelengths, have to be taken into consideration (Kräbs et al. 2002).

Not the whole red algal thallus is uniformly responding to the ambient solar conditions, but especially young apical or marginal zones, i.e., growing cells synthesise and accumulate MAAs leading to cross sectional and longitudinal concentration gradients (Hoyer et al. 2001). Older tissue regions exhibit thicker cell walls and a leathery texture, and are therefore optically well protected. In contrast, higher MAA concentrations in the most exposed outer cortex are essential to guarantee protection of the delicate meristematic cells.

Besides the stimulating effect of increasing solar radiation on the biosynthesis and accumulation of MAAs in macroalgae other environmental factors may also act as controlling parameter. Particularly lower temperatures have been experimentally proven to stimulate the MAA concentration of Antarctic Rhodophyta (Hoyer, unpublished data). Nutrient availability may also affect the MAA contents (Korbee et al. 2005). Some MAAs also exhibit antioxidative activity (Dunlap and Yamamoto 1995). However, further functional abilities of MAAs are unexplored in macroalgae.

Also in this example, the genetically determined ability to synthesise UV-screening MAAs in the different species of seaweeds is closely related to the spatial structure of the algal community in the field. In summary, the comparison of the species-dependent ability to form UVscreening compounds under laboratory and field conditions provide strong indications for differential genetic preadaptations to the potentially harmful radiation at the natural growth site.

\section{Phenolic compounds}

A special class of polyphenolic compounds are phlorotannins, which are exclusively found in brown seaweeds (Ragan and Glombitza 1986). Phlorotannins are secondary metabolites and occur in tissue concentration of up to $20 \%$ of the algal dry weight. Several functions are commonly accepted, including a role in adhesion and a strengthening role in cell walls (Schoenwaelder 2002b). Phlorotannins absorb UV radiation, mainly UVC and partly UVB, with maxima at $195 \mathrm{~nm}$ and $265 \mathrm{~nm}$ (Ragan and Glombitza 1986; Pavia et al. 1997; Henry and Van Alstyne 2004). As tannins of higher plants, phlorotannins possess a high antioxidant activity. Thus, phlorotannins are important for scavenging cell toxic reactive oxygen species (ROS), such as superoxide anion radicals produced by harmful UVB radiation. Therefore, phlorotannins are proposed to function in protecting against excess irradiance, in particular ultraviolet radiation, by screening UV radiation and/or by being an antioxidant.

We suggest four strategies to consider phlorotannins as UV-protecting compounds (1) a generally high tissue concentration of phlorotannins that absorb harmful radiation and prevent cell damages, (2) an induction of phlorotannins stimulated by harmful radiation, (3) an exudation of phlorotannins in the surrounding medium shielding harmful radiation, or (4) an excess inclusion of phlorotannins in cell walls shielding harmful radiation.

High concentrations of phlorotannins in the outer cell layers protect Hormosira banksii from sunburn during Australian summer 
(Schoenwaelder 2002a). While the outer cell layers are damaged and disrupted by sunlight, phlorotannins are released from the phlorotannin containing vesicles, the physodes, into the cytoplasma where they cause oxidative burn. Oxidised phlorotannins become brownish and form a dark brownish protective cell layer for the underlying photosynthetic tissue. Similarly, the high density of physodes at the periphery of egg and zygote cells of Fucus spiralis is most probably responsible for the high tolerance to UV-exposure, in contrast to $F$. serratus, in which physodes are less abundant (Schoenwaelder and Wiencke 2000; Schoenwaelder et al. 2003).

An induction of phlorotannins after a 2-week exposure of artificial UVB radiation was first described in Ascophyllum nodosum (Pavia et al. 1997). A weaker response was found in A. nodosum when exposed to natural UVB radiation (Pavia and Brock 2000). In that study significant differences in the phlorotannin content of UVB treated and untreated individuals were found after 7 weeks of exposure to natural UVB radiation, while only slightly increased phlorotannin concentrations were measured in the UVB treated individuals at week 2 and week 4 . An induction of phlorotannins due to UVB and UVA radiation was also described for Macrocycstis integrifolia (Swanson and Druehl 2002). In contrast, no induction of phlorotannins was found in juveniles and embryos of Fucus gardneri after 3-week exposure to UV radiation, while growth of embryos was inhibited and growth of juveniles was not affected by UVB radiation (Henry and Van Alstyne 2004). An increase in the size of physodes was observed in various Laminariales from Spitsbergen after UVB exposure indicating an induction of phlorotannin synthesis (Wiencke et al. 2004a). This has recently been verified in the UV tolerant species Alaria esculenta and Saccorhiza dermatodea. The absorbance of zoospore suspensions from these species increased considerably after UVB exposure, whereas the absorbance of spore suspensions of the UVB sensitive species $L$. digitata did not change at all (Roleda et al. 2006c).

An exudation of phlorotannins as response to artificial UVB radiation was observed in Macrocyctis integrifolia (Swanson and Druehl 2002). As a result UVB transmission through the water column was reduced, thereby protecting germinating meiospores of Laminaria groenlandica against harmful UVB radiation. Similarly, biofilters containing phloroglucinol (the monomer of phlorotannins) mitigated the harmful effect of UV-exposure on developing zygotes and embryos of Fucus serratus (Schoenwaelder et al. 2003). Biofilters made of UV transparent acrylic sheet, filled with zoospore suspensions of $S$. dermatodea, A. esculenta, L. digitata or phloroglucinol showed a varying capacity to protect zoospore cultures from the lethal effects of UVB (Roleda et al. 2006c). Generally, high phlorotannin content and high exudation rates might reflect an adaptation of seaweeds to enhanced UV radiation. Induction and variable exudation rates of phlorotannins reflect the acclimation potential to environmental changes.

Do phlorotannins play a role in the determination of depth zonation of brown algae? Evidence was found in zygotes and embryos of Fucus species (Schoenwaelder and Wiencke 2000; Schoenwaelder et al. 2003). F. spiralis from the high intertidal zone is less sensitive to UV-exposure and contains much more physodes than $F$. serratus, which is found further down the shore. Similarly, zoospores of Laminaria digitata, growing on Helgoland in the upper sublittoral, exhibit a strong absorbance below $300 \mathrm{~nm}$, indicative of phlorotannins, compared to zoospores of the mid and lower sublittoral Laminaria species (Roleda et al. 2005a). Phlorotannins may also play a role for the UV-sensitivity of zoospores of Arctic Laminariales from different depths (Wiencke et al. 2004a). Similarly, higher phlorotannin concentrations were found in Desmarestia anceps collected in shallow waters compared to deep water samples, which might indicate an induction of phlorotannins due to higher irradiances and/or UV exposure (Fairhead et al. 2005). Conversely, D. menziesii shows no differences in phlorotannin concentrations in samples from different collecting depth and even exhibits lower concentrations than $D$. anceps, which usually occurs in deeper waters (Fairhead et al. 2005).

In contrast to the data sets available on potential UV-screens in red and brown algal species information on specific UV-absorbing 
compounds in marine green algae is still very limited. Very recent studies demonstrated the solely UVB-induced increase in thallus absorption in Ulva pertusa with a maximum at $295 \mathrm{~nm}$ (Han and Han 2005), however, the responsible screening compound is still unidentified.

\section{DNA damage and repair}

As outlined above, a particularly hazardous event of UV-exposure is the induction of DNA damage. Thus strategies in order to prevent damage or to efficiently repair existing damage represent acclimation mechanisms of crucial importance. Differential induction and accumulation of UVB-induced cyclobutane-pyrimidine dimers (CPD) were measured in several red macroalgae from Brittany and Spitsbergen (van de Poll et al. 2001, 2002). In the course of 15 days repeated exposure to artificial UV radiation, no accumulation of DNA damage but rather a decrease in CPD concentration was observed in the temperate littoral species Palmaria palmata and Chondrus crispus. Conversely, an approximately 6-fold increase in the amount of CPD was observed in sublittoral species Phycodrys rubens and Polyneura hilliae (van de Poll et al. 2001). In Arctic red macrophytes, the amount of solar radiation-induced CPD concentrations in Devaleraea ramentacea, Palmaria palmata, Odonthalia dentata, Coccotylus truncatus and Phycodrys rubens (van de Poll et al. 2002) is related to their upper depth distribution limit in Kongsfjorden described by Wiencke et al. (2004b). In shallow coastal waters, blooms of floating Ulva are exposed to the full solar radiation. The amount of thallus DNA damage is, however, relatively low ranging from 1.0 to $1.88 \mathrm{CPD} \mathrm{Mb}^{-6}$ depending on solar exposure of the investigated canopy layer (Bischof et al. 2002b) compared to those reported in red macrophytes (van de Poll et al. 2001, 2002). These data suggest that the low sublittoral habitat of the Ceramiales ( $P$. hilliae, $C$. truncatus and $P$. rubens) is primarily due to their lack of tolerance to UV radiation and that UV protection mechanisms are not sufficient to prevent the accumulation of DNA-damage in these species.
Obviously, UV-susceptibility of DNA damage is highly depending on the respective developmental stage of the species under investigation. The impact of UVB-induced DNA damage on the early life stages of macroalgae is important in shaping up community structure and zonation pattern. DNA damage in carpospores of eulittoral Mastocarpus stellatus and Chondrus crispus (Roleda et al. 2004) was lower compared to zoospores of the sublittoral Laminariales in Helgoland (Laminaria digitata, L. saccharina and L. hyperborea; Roleda et al. 2005a) and Spitsbergen (Saccorhiza dermatodea, Alaria esculenta and $L$. digitata; Roleda et al. unpublished data). The UV-sensitivity of the carpospores and zoospores were related to the depth distribution of the foliose gametophyte and adult sporophytes, respectively. In the subsequent life history stage investigated, young gametophytes and sporophytes were less susceptible to UVB-induced DNA damage compared to spores. No detectable CPDs were observed in the young foliose gametophyte stages of the eulittoral $M$. stellatus and C. crispus (Roleda et al. 2004). Conversely, the remaining tissue DNA damage among juvenile Laminariales sporophytes was observed to be dependent on the thallus thickness and optical property (Roleda et al. 2005b, 2006a, 2006b). Increasing thallus thickness and opacity (in relation to available cell-bound UV-absorbing compounds) minimise UV-effects where outer phlorotannin-rich cortical layers can selectively filter short UV-wavelength from reaching the UV-sensitive targets (i.e., chloroplasts).

Less genetic damage was incurred in diploid carpospores compared to haploid zoospores (Roleda 2006). Zoospores were, however, found to be more efficient in DNA damage repair. In a sexual organism, the advantage of both ploidy states can be combined by spending much of the life cycle in the haploid state, then fusing to become diploid. During the diploid state DNA damage can be repaired, since there are two copies of the gene in the cell and one copy is presumed to be undamaged (Long and Michod 1995). In the life history of Laminariales, haploid zoospores were more sensitive to DNA damage compared to the diploid young sporophytes. 
Between the investigated Gigartinales, the lower DNA damage and effective DNA damage repair mechanism in carpospores of $M$. stellatus is responsible to its recruitment success and colonization of the upper eulittoral zone effectively changing the rocky intertidal biotope of Helgoland (Roleda et al. 2004).

\section{Acclimation via morphogenetic variation}

Several morphogenetic effects have been described for higher plants grown under UVB irradiation. Compared to white light, UVB exposed plants exhibit reduced leaf area and stem growth, but increased leaf thickness (Tevini and Teramura 1989; Mepsted et al. 1996). Information on UVinduced morphogenetic effects on the thalli of marine macroalgae is very limited. Studies on the brown alga Alaria esculenta have shown that UVB radiation results in reduced growth in length and a significant increase in fresh weight, indicative for increasing thallus thickness (Michler et al. 2002). In previous studies on various Laminariales and seagrasses it was shown that thicker thalli generally exhibit a higher UV-tolerance than thin thalli (Dawson and Dennison 1996; Dring et al. 1996a; Hanelt et al. 1997b). On the other hand, blades of the southern kelp Lessonia nigrescens are more UV sensitive than stipes and holdfasts, which has been though as a strategy to minimise mortality. In this species, the higher UV damage is concentrated in the phylloids, which are transient and with high turnover rate, whereas the massive stipes and holdfast, which are supporting structures, are less exposed to UV radiation (Gómez et al. 2005b). In general, the individual effects of UVB radiation on algal thalli with differences in morphological features are largely unexplored, thus we lack information on how UVB might influence the individual thallus structure of the individual seaweed.

Vertical versus latitudinal distribution

\section{Depth zonation}

Ecophysiological studies indicate a general correlation between stress tolerance and vertical distribution of seaweeds (Davison and Pearson
1996; Hanelt 1998). Hitherto, there is agreement that the species sensitivity to solar radiation stress is a function of depth distribution (Dring et al. 1996b; Larkum and Wood 1993; Hanelt et al. 1997a, c; Hanelt 1998; Bischof et al. 1998a; Yakovleva et al. 1998). Moreover, some authors regard solar UVB as one of the most important factors controlling the upper distribution limit of seaweeds in the field (Maegawa et al. 1993). Therefore, it is reasonable to assume that increased UVB, penetrating deeper into the water column, may result in a shift of the upper distribution limit of single species to greater water depths.

Larkum and Wood (1993) were the first who have stressed the correlation between UV-tolerance and the depth-zonation of marine macroalgae. For the vertical distribution of tropical seagrasses UV radiation was also proven to be an important factor (Dawson and Dennison 1996). Dring et al. (1996b) showed that sensitivity to UV in red algae growing around the island of Helgoland (Germany) varies with species and depth of collection. As for UVB radiation, investigations on the photoinhibition induced by high levels of PAR also shows a correlation between depth-zonation and the ability for dynamic photoinhibition of macroalgae both from sublittoral (Hanelt 1992, 1998; Hanelt et al. 1994, 1997a) and intertidal populations (Gómez et al. 2004)

In support of this concept the green algae Enteromorpha bulbosa and Acrosiphonia arcta which occur in the middle and lower eulittoral at the Antarctic Peninsula (Wiencke and Clayton 2002) do almost show no negative UV-effects on photosynthesis and are able to acclimate to even further elevated UV-exposure within hours or days (Bischof et al. 1998a). In contrast, the brown algae Desmarestia antarctica and D. anceps are described for the middle sublittoral zone off the Antarctic Peninsula (Klöser et al. 1996) but grow mostly in greater depths and occur only occasionally in depths shallower than $17 \mathrm{~m}$. In these depths biologically relevant doses of UVB radiation occur only in very transparent waters, under clear skies and at a high solar declination (Karentz 1989). This might explain why $D$. anceps is quite sensitive to UVB radiation. The red alga 
Gymnogongrus antarcticus occurs from the upper sublittoral zone down to $20 \mathrm{~m}$ (Klöser et al. 1996), i.e., the upper distribution limit is similar to that of the brown algae D. anceps and Himantothallus grandifolius and upon UVB exposure these three species show a similar inhibition rate of photosynthesis. H. grandifolius is found at $5 \mathrm{~m}$ (Lamb and Zimmermann 1977) with the lowest depth at $90 \mathrm{~m}$ (Zielinski 1990). This zonation pattern is in line with its high sensitivity. Finally, the red algae Phycodrys austrogeorgica and Delesseria lancifolia are described for the middle sublittoral zone (Delaca and Lipps 1976; Zielinski 1990; Klöser et al. 1996), but they grow under canopy plants such as $D$. anceps and $H$. grandifolius. This explains their extreme sensitivity to UV radiation. These plants may lack all protecting mechanisms against excessive radiation, because recovery from UV-exposure is poor in both species. The observed differences in species dependent UV-sensitivity are as outlined above genetically determined.

The decisive role of UVB radiation in determining vertical zonation patterns in seaweeds was recently evidenced in studies on the UV effects on the particularly sensitive developmental and reproductive stages. Only few studies were conducted using the unicellular propagation units of seaweeds, although it is widely recognised that the early developmental stages are the most susceptible to a variety of anthropogenic stresses (Coelho et al. 2000).

Seaweed propagules, spores, gametes and zygotes, are the unicellular products of asexual and sexual reproduction and have essential functions in the life-history of seaweeds with respect to dispersal, settlement, attachment, survival and recruitment (Clayton 1992; Norton 1992). They are naked cells, bounded by a plasma membrane, and in some species covered by a layer of mucilage. Their size ranges from $2 \mu \mathrm{m}$ to $>250 \mu \mathrm{m}$ in diameter and determines the sinking rate in the water column (Okuda and Neushul 1981). Brown and green algal spores and gametes are flagellated and usually small, between $3 \mu \mathrm{m}$ and $10 \mu \mathrm{m}$ in diameter (Henry and Cole 1982; Clayton 1992). Zygotes of the brown algal order Fucales have diameters between $60 \mu \mathrm{m}$ and $250 \mu \mathrm{m}$ (Clayton 1992; Schoenwaelder et al. 2003). Spores of red algae are between about $10-100 \mu \mathrm{m}$ in diameter (Clayton 1992). A positive phototaxis is found in spores of the brown algal genus Ectocarpus (Müller 1977) and the green algal genus Ulva (Evans and Cristie 1970), a negative phototaxis is found in some primitive Laminariales including Saccorhiza dermatodea. However, the capability for active swimming over long distances is rather limited. Even motile propagules have little control over their fate. The range of dispersal is at least $200 \mathrm{~m}$ and is driven mainly by currents and water motion (Norton 1992; Frederiksen et al. 1995). The number of chloroplasts per propagule can be very low. The zoospores e.g. of the more advanced families of the Laminariales, the Alariaceae, Laminariaceae and Lessoniaceae only contain one small chloroplast (Henry and Cole 1982), with comparatively low photosynthetic activity (Amsler and Neushul 1991; Wiencke et al. 2000). Storage lipids are certainly the main energy source of spores, supporting swimming and potentially germination processes (Brezezinski et al. 1993; Reed et al. 1999).

Among the different stages in the life-cycle of seaweeds the unicellular propagules are clearly the stages most susceptible to UV radiation. Germination of Ectocarpus rhodochondroides spores is inhibited by UVB, while adult specimens survive (Santas et al. 1998). Similarly, the photosynthetic efficiencies $\left(F_{\mathrm{v}} / F_{\mathrm{m}}\right)$ of sporophytes and zoospores of Laminaria digitata differ strongly when exposed to PAR, PAR + UVA or PAR + UVA + UVB (Wiencke et al. 2000). Irrespective of the radiation treatment large sporophytes show always considerably higher $F_{\mathrm{v}} / F_{\mathrm{m}}$ values compared to zoospores. Motile zoospores of Lessonia nigrescens and L. trabeculata from Chile are more UV susceptible than settled spores, gametophytes and young sporophytes (Véliz et al. 2006). The macrothalli of red algae Mastocarpus stellatus and Chondrus crispus are relatively UV tolerant whereas their carpospores are not (Bischof et al. 2000b; Roleda et al. 2004). Similarly, photosynthetic efficiency of zoospores of the green alga Ulva intestinalis exhibits an up to 6-fold higher UVB sensitivity compared to the mature thalli (Cordi et al. 2001). Interestingly, the UV susceptibility of the gametes is even greater. 
The UV susceptibility of the photosynthesis and of the DNA in spores is unequivocally related to the depth distribution of the macrothalli as outlined above (see chapters 5.1, 5.1.1.3; Bischof et al. 2000a; Wiencke et al. 2000; Roleda et al. 2004, 2005a). Other negative effects of UV radiation especially on macroalgal spores presumably important for determination of the upper distribution limit concern the cytoskeleton. The phototactic response of zoids of the brown algae Scytosiphon lomentaria and Petalonia fascia is negatively influenced by UVB (Flores-Moya et al. 2002). Moreover, the motility of zoospores of L. saccharina is affected by UVB depending on the actual UV doses (Makarov and Voskoboinikov 2001). This might be related to the observation by Huovinen et al. (2000) who reported that the nuclear division of spores of Macrocystis pyrifera is inhibited after UVB exposure. Both nuclear division and the activity of the flagellar apparatus depend on a functional microtubular system, which might be damaged by UV. This would explain also the drastic affects on zygotes observed in Fucus serratus and F. distichus (Schoenwaelder et al. 2003). No polarisation has been observed in UV exposed zygotes, rather, they remain spherical and there is no further development. Similarly, amphibian and fish zygotes remain undifferentiated and this has been related to UV effects on the microtubuli (Scharf and Gerhard 1983; Strahle and Jesuthasan 1993). The actin cytoskeleton may be affected as well as studies on other fucoids suggest. Actin inhibitors prevent polarisation, cross wall formation and vesicle movement (Schoenwaelder and Clayton 1999), the same effect as after UV treatment of zygotes of the two Fucus species (Schoenwaelder et al. 2003).

In spores the balance between the damaging effects of UV radiation and the various repair and protective mechanisms is indicated by the integrative parameter germination. If germination is not inhibited after UV exposure the repair and protective mechanisms are strong enough to outweigh the damaging effects of UV. Spore vitality after UV exposure in $M$. stellatus is higher compared to $C$. crispus, probably due to the higher capability for DNA repair in Mastocarpus (Roleda et al. 2004). In this context the size of the algal propagules may be of importance as the UV susceptibility of zoospores of various Laminariales from the eastern Pacific depends on the size of the spores (Swanson and Druehl 2000). The spores most tolerant to UV stress come from shallow water species, whereas the progeny of kelps occupying low-level UV-environments exhibit a lower germination capacity after UV stress. These results are similar to studies of phytoplankton species, in which larger organisms are more tolerant to UV exposure (Karentz et al. 1991b).

A clear dependence of the UV susceptibility of germination and growth of sporelings of coralline algae on the radiation conditions in the habitat of the various species has been demonstrated by Bañares et al. (2002). Spores from species in sunexposed habitats in the eulittoral were more UV tolerant than spores from a species growing in shaded crevices. Similarly, zygotes of $F$. serratus from the mid eulittoral on Helgoland show an abnormal development after UV exposure, whereas zygotes of $F$. spiralis, a species from the upper eulittoral much stronger exposed to UV, is not affected by the same UV treatment (Schoenwaelder et al. 2003). A clear dependence of the upper depth distribution limit of seaweeds on the UV susceptibility of their spores has also been proven for the three Laminaria species from Helgoland mainly due to the different DNA repair capacities and the different content of UV absorbing compounds (Roleda et al. 2005a). Similarly, the UV tolerance of different brown algae from Spitsbergen determines the upper depth distribution limit as indicated by experiments in the laboratory (Wiencke et al. 2000, 2004) and in the field (Wiencke et al. 2006).

\section{Microscale gradients in UVB exposure}

Pronounced acclimation of photosynthesis to UV exposure does also take place along microscale gradients as for example in algal mats: Green algal mats do frequently occur as a result of eutrophication in sheltered coastal lagoons. Within these mats usually a steep gradient of solar radiation occurs (Vergara et al. 1997): Top layers are exposed to high surface irradiance, whereas bottom layers are permanently exposed 
to very low light conditions or even stay in darkness. It has been show for the two bloomforming green algal species Ulva rotundata and Chaetomorpha linum that UVB irradiance substantially contributes in structuring these mat-like canopies (Bischof et al. 2002b, 2003, 2006). Inside the mats, strong gradients are visible for solar (UVB) radiation, but also for physiological responses: loss in photosynthetic pigments and proteins is strongly pronounced in top layers and is diminished with increasing depth inside the mat. Photosynthetic activity is inhibited in the top layers, performs at maximum rates in intermediate thallus layers and, due to light limitation, is again strongly reduced in bottom layers (KrauseJensen et al. 1996; Vergara et al. 1997; Bischof et al. 2002b). A specific response to the degree of UVB exposure inside these mat-like structures is the specific activity of superoxide dismutase (SOD), an enzyme responsible for the scavenging of superoxide anions generated in photosynthesis under stress full conditions (Bischof et al. 2003, 2006). Depending on the degree of UVB exposure and inhibition of photosynthesis along the depth gradient, the activity of SOD becomes stimulated. Two mechanisms might be involved in this response: either the enzyme becomes activated due to a light effect (due to exposure to short wavelength radiation) or it is the presence of previously generated oxygen radicals (ROS) which act as trigger for increasing SOD activity (Bischof et al. 2006). For higher plants, it was shown that ROS play an important signalling role in signal transduction pathways, in order to respond to UVB exposure (Mackerness et al. 1999).

\section{From the tropics to the poles}

As the problem of ozone depletion is rather restricted to the polar and temperate regions, organisms inhabiting the (shallow water zone of) tropical regions are unlikely to be affected by seasonally enhanced UVB irradiance, but are of course permanently exposed to much higher UV levels than encountered in polar regions (even under ozone depleted conditions). Thus, tropical species must have developed particularly effective protection strategies in response to high UVB irradiance. Unfortunately, data on UVB protection in tropical species as well as comparative studies on related species from different geographical regions are extremely scarce and the limited information available is not conclusive. In a study on different species of the green alga genus Cladophora no hints were found for a particular higher UVB tolerance of a true tropical species (C. zolingerii from the Philippines) compared to its cold-temperate congener C. rupestris (Bischof and van de Poll unpublished data). Preliminary data on UVB absorption characteristics within the cell wall of both species did not provide any hint for a more effective UVB shielding in the tropical species. Moreover, also physiological parameters tested did not point to a particularly higher UVB tolerance of the tropical species compared to the congener from temperate waters.

Like at the species level, studies on latitudinal UV-patterns at the community level are extremely scarce. To our knowledge, only the study by Wahl et al. (2004) investigated UV-effects on shallow-water macro-epibenthic assemblages at different bio-geographical regions. Their study revealed a consistent pattern of UV-effects at both hemispheres. Species richness and community biomass were negatively affected by UV-treatments. Surprisingly, effects by UVA were more detrimental than those of UVB. UV-effects were transient, disappearing at $80 \%$ of all sites within 2-3 months, but persisted at one polar (Norway) and one tropical (China) site, suggesting lack of latitudinal patterns of UV-effects at the community level.

\section{Ecological implications-UVB and the structure of seaweed communities}

The consequences of enhanced UVB exposure to ecosystem function are still largely unexplored and hypothetical. However, based on the studies accomplished so far the following assumptions can be made.

\section{Potential effects on primary productivity}

Throughout the previous studies, it is shown that all species, which have to withstand UVB in the 
field (i.e., the species inhabiting the intertidal and the upper sublittoral zone) possess different and largely efficient mechanisms for acclimation to respond to changes in light climate. However, formation of screening compounds as well as the development of further protective mechanisms require additional energy costs, which may result in reduced growth and primary productivity (Roleda et al. 2006a). This problem is still largely unaddressed but an important field of future investigation. As long as the energy costs for applying protective mechanisms remain unknown a reduction of seaweed productivity in response to increased UVB levels in future cannot be excluded.

Reduced reproductive success and shifts in age structure

The information available on UV-susceptibility of different developmental stages indicates the unicellular spores and zygotes as being most sensitive. Other information on how UV-exposure may affect reproduction and the timing of developmental cycles is hardly available. It is obvious that increased UV-induced spore mortality will result in impaired reproductive success, but may also affect the age structure of seaweed populations (Wiencke et al. 2000, 2004a). Due to high interannual variations in light climate particularly in polar areas (Hanelt et al. 2001) high UV-irradiance may affect zoospore survival in shallow waters in 1 year, as in another year it may not. Thus new recruits are only likely to develop to adult sporophytes if they are protected from high UVB exposure. In certain years with particularly high fluences of UVB reaching the benthic communities a new generation of recruits might therefore fail to develop, while larger age and size classes of sporophytes were rather unaffected due to the already accomplished acclimation on a physiological and morphological base (Altamirano et al. 2003a, b).

Downward shifts in depth distribution

As outlined above there is now evidence, that the species sensitivity to solar radiation stress is a function of depth distribution (Larkum and Wood
1993; Dring et al. 1996b; Hanelt et al. 1997a, c; Hanelt 1998; Bischof et al. 1998a; Wiencke et al. 2006). For several physiological parameters a strong correlation of UVB sensitivity and vertical position on the shore was shown for numerous species (van de Poll et al. 2001, 2002; Bischof et al. 1998a, Gómez et al. 2004, Wiencke et al. 2006). Therefore, it is reasonable to argue that increased UVB, penetrating deeper into the water column, results in a shift of the upper distribution limit of single species to greater water depths. However, at least in the macrothalli several acclimation processes can counteract radiation stress, but the particular sensitivity of spores may be the decisive aspect in this scenario, thus preventing recruitment in shallow waters with high UVB irradiances. Through this process, elevated UVB may result in a shift of seaweed communities to deeper waters (Wiencke et al. 2006).

\section{Succession}

Species do not exist in isolation. Rather, multiple species form complex, interacting habitat-specific communities. Results from physiological studies at the species level might not reflect biological responses when repeated at the community level due to e.g., indirect or synergistic effects. Consequently, it seems reasonable that an ultimate assessment of UV-effects should be inferred at the community level (Bothwell et al. 1994). Open space represents a key resource for many species of seaweeds and its colonisation is characterised by a series of species replacements (Sousa and Connell 1992). Three alternative successional models have been proposed by Connell and Slatyer (1977). The facilitation model suggests that initially the propagules of a few species will recruit on open space and their existence will modify the substratum for the settlement of other species. The tolerance model predicts a neutral effect of early on later colonizers with the latter replacing early colonizers due to more efficient resource use by competitive exclusion. Under the inhibition model, early settlers pre-empt the substratum, hindering invasion of subsequent species. The predictions of these models may be altered by overlaying patterns of climatic or 
ecological factors (e.g., grazing Farrell 1991; Sousa and Connell 1992).

Only a few studies assessed UV-effects during species succession of shallow-water seaweed-dominated communities (Santas et al. 1998; Lotze et al. 2002; Molis et al. 2003; Molis and Wahl 2004; Wahl et al. 2004; Dobretsov et al. 2005). Surprisingly in all but one study (Dobretsov et al. 2005), UV-effects were only apparent during the early phase of succession. In the study by Dobretsov et al. (2005) it seemed very unlikely that later successional species could cope with UV-effects by acclimatizing at the same time to the UV-regime, e.g., by induction of UV-screening substances. Alternatively and more likely, transient UV-effects during community assemblage might result from intra- and interspecific differences in the susceptibility to UV-exposure for which experimental evidence exists. For instance, differential UV-sensitivities of carpospores influenced recruitment success of two competing Gigartinales-species, partly explaining vertical zonation patterns of both species (Roleda et al. 2004). Similarly, spores from deeper dwelling species exhibit higher mortality rates compared to spores from shallow water species (Wiencke et al. 2000, 2004a, 2006). Moreover, sorus of Laminaria digitata is completely opaque, resulting in a sudden and drastic change in UVexposure ('UV-shock') for released zoospores (Gruber, pers. communication). Finally, several seaweed species, e.g. green filamentous forms, seem particularly well adapted to recruit at UVexposed sites in the upper eulittoral, i.e., where UV-irradiance is strongest on the shore, and it was experimentally demonstrated that their abundance correlates positively with UV-exposure time (Molis et al. 2003). The invasion of sites high on the intertidal shore might be a selective advantage, as this guarantees a relative shorter exposure to grazers compared to sites lower on the shore. Thus, macroalgal propagules may show species-specific differential UV-sensitivities, which favour initial colonisation of empty space by UV-resistant species. Wahl et al. (2004) suggested that these early colonizers facilitate the recruitment of later successional seaweed and invertebrate species at the majority of their study sites by amelioration of UV-regimes due to protective shading. Similarly Vinebrooke and Leavitt (1999) concluded that diatom mats can precondition the substratum for macroalgal spores by provision of UV-free micro-climates.

The effect of UVB exposure on the early succession of macroalgae was also studied at a rocky intertidal platform at King George Island, Antarctica, revealing a significant reduction of species diversity based on the effects of UVB (Zacher et al. unpublished data). Species recruitment and dry weight was monitored over a period of 15 weeks on artificial substrates exposed in the intertidal zone. Natural UVexposure was found to affect the density of the green alga Monostroma hariotii in the first 10 weeks of the experiment, whereas the density of red algal recruits decreased significantly due to UV after 8 and 15 weeks, respectively. Shannon diversity $H^{\prime}$ dropped as succession proceeded in the PAR + UVA + UVB treatment, increased slightly in the PAR + UVA treatment, and increased in the PAR treatment from the beginning until the end of the experiment. Furthermore, the treatment with PAR alone resulted in a significantly higher diversity at the end of the experiment than the treatment including the total UV-range. After 15 weeks the community excluded from UV radiation showed a significantly higher diversity, evenness and number of red algal germlings and species than communities exposed to the whole solar spectrum. This led to a significant dissimilarity in species composition between these two communities. Diversity was negatively influenced by both UVA and UVB radiation. The results show that Antarctic macroalgal recruits are particularly sensitive to UV-exposure during their first month of development, but that effects change during succession.

\section{Competition}

Very few examples of UV-mediated changes in competitive abilities of macroalgae exist (Bischof et al. 2000b; Roleda et al. 2004). However, UV-exposure may quite commonly affect the competitive ability of a macroalgae, if UV-induced changes, e.g., production of MAAs, represent a metabolic cost for the alga. Moreover, the competitive ability of seaweeds may be negatively 
affected, if UVB has detrimental effects on growth. As a result, the algae will be shaded by more UV-resistant species and experience further reduced growth due to limited PAR-regimes, similar to what has been predicted for terrestrial plants (Caldwell et al. 1989).

Several species of algae are known to affect the community structure of nearby developing benthic assemblages (Wahl 2001). One possible mechanism of this biogenic neighbourhood effect is the exudation of metabolites that influence settlement. Little is known about UV-induced changes in chemical composition of macroalgal exudates and the possible indirect effects of UVexposure on the structure and species composition of communities that establish in the vicinity of macroalgae. For example, tri-hydroxycoumarins (phenolics) excreted by the green alga Dasycladus vermicularis in response to enhanced radiation conditions protects other macroalgal species from UV-exposure (Pérez-Rodriguez 2000). UV-resistant seaweeds may have a selective advantage over UV-sensitive species by indirectly reducing herbivory. Given that two species of macroalgae have identical physiological properties, except with respect to UV-susceptibility, one would expect the less sensitive species to occur higher on the shore, i.e., where UV-regimes are more severe than lower on the shore, than the UV-sensitive counterpart. Consequently, the UV-sensitive species would be exposed over longer periods to motile consumers, e.g., isopods, and other important herbivores, e.g. sea urchins.

\section{Alga-herbivore interactions}

The consumption of plant biomass represents the most fundamental plant-animal interaction, affecting biomass accrual and community composition of photoautotrophs (Sousa and Connell 1992; Duffy and Hay 2000). Consequently, herbivory is one key factor controlling the central ecosystem services of primary producers. Grazing intensity is considered to be lower on terrestrial plants than on aquatic macrophytes (Cyr and Pace 1993), due to a higher availability of seaweed biomass to herbivore attacks, the larger proportion of digestible algal biomass (Hay 1991), and higher mass-specific consumption rates of aquatic herbivores (Cyr and Pace 1993). As a result, aquatic plants may be more strongly top-down controlled than terrestrial counterparts and, thus, trophic interactions in aquatic habitats may be of stronger ecological outreach, e.g., in driving algal recruitment (Diaz-Pulido and McCook 2003), community succession (Farrell 1991) or mediating stability-diversity-productivity relationships of communities (Worm and Duffy 2003).

Seaweeds actively participate in the interaction with herbivores by tolerating consumption with compensatory growth (Cronin 2001), escape from herbivory (Hay et al. 1988), or the defence of grazing (e.g., Cronin 2001). Anti-herbivory defences in seaweeds may either be permanently expressed (constitutive) or induced in response to herbivory (Amsler and Fairhead 2006). Experimental evidence suggests that the induction of anti-herbivory defences is of selective advantage in variable grazing regimes (Karban and Nagasaka 2004), while constitutive defences are more beneficial to algae under a constant herbivory load (Karban et al. 1999). Induced chemical anti-herbivory defences can result in reduced consumption of previously attacked tissues (Ceh et al. 2005), increased feeding dispersal with a concomitant higher risk of herbivores becoming visible to predators (Borell et al. 2004) or both (Borell et al. 2004). The induction of anti-herbivory defences in seaweeds is known to be tissue- and (Sotka et al. 2002; Taylor et al. 2002) grazer-specific (Pavia and Toth 2000; Molis et al. 2006) and that at least some of this specificity is seasonally variable (Molis et al. 2006). Thus, phenotypic plasticity of algal responses to herbivory adds complexity to the trophic interactions between algae and their consumers. Furthermore, seasonality in inducible defences suggests that top-down forces may vary under variable environmental conditions, e.g., UV-regimes.

Cronin and Hay (1996) reported that UVexposure reduced chemical defences in Dictyota ciliolata, making this brown seaweed more palatable to sea urchins and to a lesser extend also to amphipods. The selected UV-exposure time represents common emergence periods for intertidal algae. Consequently, UV-exposure seems to have 
the potential to increase algal susceptibility to consumers, especially during summer, i.e., at maximum UV-levels. However, algae form multi-layered piles during low tide, suggesting that only top-layered individuals are fully affected by UV, while specimens positioned deeper in the pile are protected to some extend from UVexposure. Similar indirect UV-protective effects are known from cyanobacterial mats (Karsten et al. 1998b) and macroalgal dominated subtidal macrobenthic communities (Wahl et al. 2004). Furthermore, UV-effects on algae-animal interactions were absent in the study of Macaya et al. (2005) who did not detect any changes in response patterns between UV-exposed and -shielded Macrocystis individuals. This suggests that UVexposure did not alter the ability to induce antiherbivory defences in this brown macroalga, at least in the case of some invertebrates. Lotze and Worm (2002) investigated the interactive effects of UV-exposure and grazing on early life stages of a green alga. Their study revealed that the influence of ecological controls, i.e., grazers, on Enteromorpha-recruitment were stronger than climatic controls, i.e., UV and temperature, and of opposite sign.

Linking UV-effects on macroalgae with trophic interactions seems to be an interesting, but as yet not fully accounted venue for further exploiting the effects of climatic and ecological drivers on the performance and fitness of seaweeds and the species composition and productivity of seaweed communities. Presently, too few studies tested the interactive effects of UV-exposure and herbivory on alga-consumer interactions to draw general conclusions about the influence of UV-radiation on herbivory. It seems likely that UV-induced chemicals may indirectly change the susceptibility of algae to consumers by altering the function of existing chemicals, which could in- or decrease algal palatability. Alternatively, UV-induced compounds may have multiple functions. Schmitt et al. (1995) demonstrated that herbivore-deterrent chemicals displayed also anti-fouling activities. To our knowledge, only the study by Pavia et al. (1997) suggests multiple functions in UV-induced phlorotannins. The concentration of phlorotannins was lower in controls than in UV-exposed Ascophyllum nodosum, with the latter stimulating Idotea grazing. As UV-exposure is known to induce the production of many secondary metabolites (e.g., MAAs) it would be interesting to study the direct and indirect effects of these compounds on algae-herbivore interactions. For instance, UV-induced secondary metabolites may affect the anti-fouling ability of a macroalgae and altered epibiontic communities may change algal susceptibility to consumers, resulting in shared doom scenarios or associational resistance (sensu Wahl and Hay 1995).

Besides UV-induced effects on macroalgae, patterns of herbivory can also be altered by UV-effects on consumers. McNamara and Hill (1999) showed differential susceptibility of consumers to UVB, suggesting shifts in grazing regimes at sites of high UVB-exposure. Experimental evidence comes from studies on periphyton communities. DeNicola and Hoagland (1996) showed that herbivore density under UV-exposure was on average $50 \%$ reduced compared to PARtreatments at the end of a $28 \mathrm{~d}$ long experiment. Bothwell et al. (1994) reported that, in the presence of herbivores, biomass accrual in UVBexposed periphyton communities was higher than in PAR-irradiated communities. This suggests stronger negative effects at the consumer than at the producer level and, consequently, an indirect positive UVB-effect on periphytic biomass production. Future studies should focus on UV-effects on herbivores to elicit the relative harmfulness of UV-exposure on seaweeds and their consumers.

\section{Synthesis}

Under present radiation conditions, UVB radiation has already to be regarded as a common abiotic factor, which influences the physiology of individual seaweeds but does also contribute in structuring seaweed communities in various ways. However, its potential threat to biologic processes is counteracted by several adaptive strategies activating different protective and repair mechanisms. These mechanisms (e.g., formation of screening compounds, antioxidative systems, regulation of enzyme activity and gene expression, DNA repair mechanisms) serve as a physiological filter to reduce the adverse effect of the impinging 
solar UVB, in addition canopy algae also protect more susceptible subcanopy organisms from solar exposure. Based on the differential adaptation and acclimation capabilities realised in the different species UVB radiation may, even under non-depleted ozone conditions, substantially affect the structure of seaweed communities. As outlined above, UVB exposure may modulate productivity, reproduction, vertical distribution, species diversity and succession, competition and alga-herbivore interactions. However, the effect extent of each of the aspects under ozone-depleted conditions is largely unknown. To improve our knowledge on how UVB may shape seaweed communities and thus rocky coastal ecosystems in the future, further research should predominantly focus on the following three directions: (1.) UVB is not the only factor potentially causing abiotic stress to seaweed photosynthesis. Particularly the intertidal zone is characterized by large variation of abiotic parameters, furthermore anthropogenically caused increases in seawater temperature and nutrient loads also affect seaweed performance in the field. Physiological studies on the interaction of a multitude of abiotic (stress) factors are indispensable. (2.) The molecular mechanisms triggering acclimation strategies are largely unknown. The application of molecular tools also in seaweed physiology will be a major step forward in this respect. (3.) Certainly, the most serious lack of information is still present regarding the ecological interactions modulated by UVB exposure. As outlined above, only fragmentary data sets are available so far addressing how UVB is presently interfering with seaweed succession or in interactions with seaweed-associated consumers. Field studies on a large spatial and time scale would be required including the generation of UV-free, ambient UV and increased UV irradiation treatments. Such as kind of experiment is logistically ambitious but would substantially broaden our knowledge on how UVB will alter the structure of seaweed communities in the future.

Acknowledgements A large part of the studies reported here were funded by the following institutions: German Academic Exchange Service (DAAD), CONICYT Chile, German Research Foundation (DFG), European Union, Helmholtz Association of German Research Centres (HGF), Alexander von Humboldt Foundation (AvH)

\section{References}

Aguilera J, Karsten U, Lippert H, Vögele B, Philipp E, Hanelt D, Wiencke C (1999) Effects of solar radiation on growth, photosynthesis and respiration of marine macroalgae from the Arctic. Mar Ecol Prog Ser 191:109-119

Aguilera J, Gordillo FJL, Karsten U, Figueroa FL, Niell FX (2000) Light quality effect on photosynthesis and efficiency of carbon assimilation in the red alga Porphyra leucosticta. J Plant Physiol 157:86-92

Allen DJ, McKee IF, Farage PK, Baker NR (1997) Analysis of limitations to $\mathrm{CO}_{2}$ assimilation on exposure of leaves of two Brassica napus cultivars to UVB. Plant Cell Envir 20:633-640

Altamirano M, Flores-Moya A, Figueroa FL (2000a) Long-term effects of natural sunlight under various ultraviolet radiation conditions on growth and photosynthesis of intertidal Ulva rigida (Chlorophyceae) cultivated in situ. Bot Mar 43:19-126

Altamirano M, Flores-Moya A, Figueroa FL (2000b) Growth seasonality, photosynthetic pigments, and $\mathrm{C}$ and $\mathrm{N}$ content in relation to environmental factors: a field study on Ulva olivascens (Ulvales, Chlorophyta). Phycologia 39:50-58

Altamirano M, Flores-Moya A, Figueroa FL (2003a) Effects of UV radiation and temperature on growth of germlings of three species of Fucus (Phaeophyceae). Aquatic Bot 75:9-20

Altamirano M, Flores-Moya A, Kuhlenkamp R, Figueroa FL (2003b) Stage-dependent sensitivity to ultraviolet radiation in zygotes of the brown alga Fucus serratus. Zygote 11:101-106

Amsler CD, Neushul M (1991) Photosynthetic physiology and chemical composition of spores of the kelps Macrocystis pyrifera, Nereocystis luetkana, Laminaria farlowii and Pterigophora californica (Phaeophyceae). J Phycol 27:26-34

Amsler CD, Fairhead VA (2006) Defensive and sensory chemical ecology of brown algae. Adv Bot Res 43:1-91

Arrigo KR, Brown CW (1996) Impact of chromophoric dissolved organic matter on UV inhibition of primary productivity in the sea. Mar Ecol Prog Ser 140: 207-216

Aro EM, Virgin I, Andersson B (1993) Photoinhibition of photosystem II. Inactivation, protein damage and turnover. Biochim Biophys Acta 1143:113-134

Bandaranayake WM (1998) Mycosporines: are they nature's sunscreens? Nat Prod Rep 15:159-172

Bañares E, Altamirano M, Figueroa LF, Flores-Moya A (2002) Influence of UV radiation on growth of sporelings of three non-geniculate coralline red algae from Southern Iberian Peninsula. Phycol Res 50:23-30

Barber J, Andersson B (1992) Too much of a good thing: light can be bad for photosynthesis. Trend Biochem Sci 17:61-66

Bischof K, Hanelt D, Wiencke C (1998a) UV-radiation can affect depth-zonation of Antarctic macroalgae. Mar Biol 131:597-605 
Bischof K, Hanelt D, Tüg H, Karsten U, Brouwer PEM, Wiencke C (1998b) Acclimation of brown algal photosynthesis to ultraviolet radiation in Arctic coastal waters (Spitsbergen, Norway). Pol Biol 20:388-395

Bischof K, Hanelt D, Wiencke C (1999) Acclimation of maximal quantum yield of photosynthesis in the brown alga Alaria esculenta under high light and UV radiation. Plant Biol 1:435-444

Bischof K, Hanelt D, Wiencke C (2000a) Effects of ultraviolet radiation on photosynthesis and related enzyme reactions of marine macroalgae. Planta 211:555-562

Bischof K, Janknegt PJ, Buma AGJ, Rijstenbil JW, Peralta G, Breeman AM (2003) Oxidative stress and enzymatic scavenging of superoxide radicals induced by solar UV-B radiation in Ulva canopies from southern Spain. Sci Mar 67:353-359

Bischof K, Kräbs G, Hanelt D, Wiencke C (2000b) Photosynthetic characteristics and mycosporine-like amino acids under UV-radiation: a competitive advantage of Mastocarpus stellatus over Chondrus crispus at the Helgoland shoreline? Helgol Mar Res 54:47-52

Bischof K, Kräbs G, Wiencke C, Hanelt D (2002a) Solar ultraviolet radiation affects the activity of ribulose1,5-bisphosphate carboxylase-oxygenase and the composition of photosynthetic and xanthophyll cycle pigments in the intertidal green alga Ulva lactuca L. Planta 215:502-509

Bischof K, Peralta G, Kräbs G, van de Poll WH, PerezLlorens JL, Breeman AM (2002b) Effects of solar UV$\mathrm{B}$ radiation on canopy structure of Ulva communities from Southern Spain. J Exp Bot 53:2411-2421

Bischof K, Rautenberger R, Brey L, Perez-Llorens JL (2006) Physiological acclimation along gradients of solar irradiance within mats of the filamentous green macroalga Chaetomorpha linum from southern Spain. Mar Ecol Prog Ser 306:165-175

Björn LO, Callaghan TV, Gehrke C, Johanson U, Sonesson M (1999) Ozone depletion, ultraviolet radiation and plant life. Chemosphere: Global Change Sci 1:449-454

Borell EM, Foggo A, Coleman RA (2004) Induced resistance in intertidal macroalgae modifies feeding behaviour of herbivorous snails. Oecologia 140:328-334

Bornman JF (1989) Target sites of UV-radiation in photosynthesis of higher plants. J Photochem Photobiol B Biol 4:145-158

Bothwell ML, Sherbot DMJ, Pollock CM (1994) Ecosystem response to solar ultraviolet-B radiation: influence of trophic level interactions. Science 265:97-100

Brezezinski MA, Reed DC, Amsler CD (1993) Neutral lipids as major storage products in zoospores of the giant kelp Macrocystis pyrifera (Phaeophyceae). J Phycol 29:16-23

Caldwell MM (1971) Solar UV irradiation and the growth and development of higher plants. In: Giese AC (ed) Photophysiology, vol 6. Academic Press, New York, pp 131-177

Caldwell MM, Björn LO, Bornman JF, Flint SD, Kulandaivelu G, Teramura AH, Tevini M (1998) Effects of increased solar ultraviolet radiation on terrestrial ecosystems. J Photochem Photobiol B Biol 46:40-52

Caldwell MM, Teramura AH, Tevini M (1989) The changing solar ultraviolet climate and the ecological consequences for higher plants. Trend Ecol Evol 4:363-367

Campbell D, Eriksson MJ, Öquist G, Gustafsson P, Clarke AK (1998) The cyanobacterium Synechococcus resists UV-B by exchanging photosystem II reaction-center $\mathrm{D}_{1}$ proteins. Proc Nat Acad Sci 95:364-369

Chapman ARO, Lindley JE (1980) Seasonal growth of Laminaria solidungula in the Canadian high Arctic in relation to irradiance and dissolved nutrient concentrations. Mar Biol 57:1-5

Ceh J, Molis M, Dzeha TM, Wahl M (2005) Induction and reduction of anti-herbivore defenses in brown and red macroalgae off the Kenyan coast. J Phycol 41:726-731

Clayton MN (1992) Propagules of marine macroalgae: structure and development. Br Phycol J 27:219-232

Coehlo SM, Rijstenbil JW, Brown MT (2000) Impacts of anthropogenic stresses on the early development stages of seaweeds. J Aquat Ecosyst Stress Rec 7:317-333

Conde FR, Churio MS, Previtali CM (2000) The photoprotector mechanism of mycosporine-like amino acids. Excited-state properties and photostability of porphyra-334 in aqueous solution. J Photochem Photobiol B Biol 56:139-144

Connell JH, Slatyer RO (1977) Mechanisms of succession in natural communities and their role in community stability and organisation. Am Nat 111:1119-1144

Cordi B, Donkin ME, Peloquin J, Price DN, Depledge MH (2001) The influence of UV-B radiation on the reproductive cells of the intertidal macroalga, Enteromorpha intestinalis. Aquat Toxicol 56:1-11

Cronin G (2001) Resource allocation in seaweeds and marine invertebrates: chemical defense patterns in relation to defense theories. In: McClintock JB, Baker BJ (eds) Marine chemical ecology. CRC Press, New York, pp 325-353

Cronin G, Hay ME (1996) Susceptibility to herbivores depends on recent history of both the plant and animal. Ecology 77:1531-1543

Cyr H, Pace ML (1993) Magnitude and patterns of herbivory in aquatic and terrestrial ecosystems. Nature 361:148-150

Davison IR, Pearson GA (1996) Stress tolerance in intertidal seaweeds. J Phycol 32:197-211

Dawson SP, Dennison WC (1996) Effects of ultraviolet and photosynthetically active radiation on five seagrass species. Mar Biol 125:629-638

DeLaca TE, Lipps JH (1976) Shallow-water marine associations. Antarctic Peninsula, Antarctic J US 11:12-20

DeNicola DM, Hoagland KD (1996) Effects of solar spectral irradiance (visible to UV) on a prairie stream epilithic community. J N Am Benthol Soc 15:155-169

Diaz-Pulido G, McCook LJ (2003) Relative roles of herbivory and nutrients in the recruitment of coral-reef seaweeds. Ecology 84:2026-2033

Dobretsov SV, Qian PY, Wahl M (2005) Effect of solar ultraviolet radiation on the formation of shallow, 
early successional biofouling communities in Hong Kong. Mar Ecol Prog Ser 290:55-65

Döhler G (1985) Effect of UV-B radiation (290-320 nm) on the nitrogen metabolism of several marine diatoms. J Plant Physiol 118:391-400

Döhler G (1992) Impact of UV-B radiation on uptake of ${ }^{15} \mathrm{~N}$-ammonia and ${ }^{15} \mathrm{~N}$-nitrate by phytoplankton of the Wadden Sea. Mar Biol 112:485-489

Dring MJ, Makarov V, Schoschina E, Lorenz M, Lüning K (1996a) Influence of ultraviolet-radiation on chlorophyll fluorescence and growth in different life history stages of three species of Laminaria. Mar Biol 126:183-191

Dring MJ, Wagner A, Boeskov J, Lüning K (1996b) Sensitivity of intertidal and subtidal red algae to UVA and UVB radiation, as monitored by chlorophyll fluorescence measurements: influence of collection depth and season, and length of irradiation. Eur J Phycol 31:293-302

Duffy JE, Hay ME (2000) Strong impacts of grazing amphipods on the organization of a benthic community. Ecol Monogr 70:237-263

Dunlap WC, Yamamoto Y (1995) Small-molecule antioxidants in marine organisms: antioxidant activity of mycosporine-glycine. Comp Biochem Physiol 112B:105-114

Ekelund NGA (1990) Effects of UV-B radiation on growth and motility of four phytoplankton species. Physiol Plant 78:590-594

Evans LV, Christie AO (1970) Studies on the ship-fouling alga Enteromorpha I. Aspects of the fine-structure and biochemistry of swimming and newly settled zoospores. Ann Bot 34:451-466

Fairhead VA, Amsler CD, McClintock JB, Baker BJ (2005) Variation in phlorotannin content within two species of brown macroalgae (Desmarestia anceps and D. menziesii) from the Western Antarctic Peninsula. Polar Biol 28:680-686

Falkowski PG, LaRoche J (1991) Acclimation to spectral irradiance in algae. J Phycol 27:8-14

Farman JC, Gardiner BG, Shanklin JD (1985) Large losses of total ozone in Antarctica reveal seasonal $\mathrm{ClO}_{x} / \mathrm{NO}_{x}$ interaction. Nature 315:207-210

Farrell TM (1991) Models and mechanisms of succession: an example from a rocky intertidal community. Ecol Monogr 61:95-113

Flores-Moya A, Gómez I, Viñegla B, Altamirano M, PerézRodríguez E, Maestre C, Caballero RM, Figueroa FL (1998) Effects of solar radiation on the endemic Mediterranean alga Rissoella verruculosa: photosynthetic performance, pigment content and activities of enzymes related to nutrient uptake. New Phytol 139:673-683

Flores-Moya A, Hanelt D, Figueroa FL, Altamirano M, Viñegla B, Salles S (1999) Involvement of solar UV-B radiation in recovery of inhibited photosynthesis in the brown alga Dictyota dichotoma (Hudson) Lamouroux. J Photochem Photobiol B Biol 49:129-135

Flores-Moya A, Posudin YI, Fernández JA, Figueroa FL, Kawai H (2002) Photomovement of the swarmers of the brown algae Scytosiphon lomentaria and Petalonia fascia: effect of photon irradiance, spectral composi- tion and UV dose. J Photochem Photobiol B Biol 66:134-140

Franklin LA, Osmond CB, Larkum AWD (2003) UV-B and algal photosynthesis. In: Larkum AWD, Douglas SE, Raven JA (eds) Photosynthesis in algae, advances in photosynthesis and respiration, vol 14. Kluwer Academics Publishers, Dordrecht, pp 351-384

Frederick JE, Snell HE, Haywood EK (1989) Solar ultraviolet radiation at the earth's surface. Photochem Photobiol 50:443-450

Frederiksen S, Sjotun K, Lein EL, Rueness J (1995) Spore dispersal in Laminaria hyperborea (Laminariales, Phaeophyceae). Sarsia 80:47-54

Gómez I, Figueroa FL, Huovinen P, Ulloa N, Morales V (2005a) Photosynthesis of the red alga Gracilaria chilensis under natural solar radiation in an estuary in southern Chile. Aquaculture 244:369-382

Gómez I, Figueroa FL, Ulloa N, Morales V, Lovengreen C, Huovinen P, Hess S (2004) Patterns of photosynthesis in 18 species of intertidal macroalgae from southern Chile. Mar Ecol Progr Ser 270:103-116

Gómez I, Pérez-Rodríguez E, Viñegla B, Figueroa FL, Karsten U (1998) Effects of solar radiation on photosynthesis, UV-absorbing compounds and enzyme activities of the green alga Dasycladus vermicularis from southern Spain. J Photochem Photobiol B Biol 47:46-57

Gómez I, Ulloa N, Orostegui M (2005b). Morpho-functional patterns of photosynthesis and UV sensitivity in the kelp Lessonia nigrescens (Laminaria, Phaeophyta). Mar Biol 148:231-240

Greenberg BM, Gaba V, Canaani O, Malkin S, Mattoo AK, Edelman M (1989) Seperate photosensitizers mediate degradation of the $32-\mathrm{kDa}$ photosystem II reaction center protein in the visible and UV spectral regions. Proc Nat Acad Sci USA 86:6617-6620

Häder DP, Häder M (1989) Effects of solar and artificial radiation on motility and pigmentation in Cyanophora paradoxa. Arch Microbiol 152:453-457

Han YS, Han T (2005) UV-B induction of UV-B protection in Ulva pertusa (Chlorophyta). J Phycol 41:523-530

Han T (1996a) Effect of ultraviolet-B radiation on Ulva pertusa Kjellman (Chlorophyta) I. Growth and pigment content. Algae Kor J Phycol 11:155-159

Han T (1996b) Far-UV action on growth, pigmentation and photosynthesis of Ulva lactuca (Chlorophyta). Algae Kor J Phycol 11:203-206

Hanelt D, Tüg H, Bischof K, Gross C, Lippert H, Sawall T, Karsten U, Wiencke C (2001) Light regime in an Arctic fjord: a study related to stratospheric ozone depletion as a basis for determination of UV effects on algal growth. Mar Biol 138:649-658

Hanelt D (1992) Photoinhibition of photosynthesis in marine macrophytes of the South China Sea. Mar Ecol Prog Ser 82:199-206

Hanelt D (1998) Capability of dynamic photoinhibition in Arctic macroalgae is related to their depth distribution. Mar Biol 131:361-369

Hanelt D, Li J, Nultsch W (1994) Tidal dependence of photoinhibition of photosynthesis in marine macrophytes of the South China Sea. Bot Acta 107:66-72 
Hanelt D, Wiencke C, Nultsch W (1997a) Influence of UV radiation on the photosynthesis of Arctic macroalgae in the field. J Photochem Photobiol B Biol 38:40-47

Hanelt D, Wiencke C, Karsten U, Nultsch W (1997b) Photoinhibition and recovery after high light stress in different developmental and life-history stages of Laminaria saccharina (Phaeophyta). J Phycol 33: 387-395

Hanelt D, Melchersmann B, Wiencke C, Nultsch W (1997c) Effects of high light stress on photosynthesis of polar macroalgae in relation to depth distribution. Mar Ecol Prog Ser 149:255-266

Hay ME (1991) Marine-terrestrial contrasts in the ecology of plant chemical defenses against herbivores. Trend Ecol Evol 6:362-365

Hay ME, Fenical W (1992) Chemical mediation of seaweed-herbivore interactions. In: John DM, Hawkins SJ, Price JH (eds) Plant-animal interactions in the marine benthos 46: 319-337

Hay ME, Paul VJ, Lewis SM, Gustafson K, Tucker J, Trindell RN (1988) Con tropical seaweeds reduce herbivory by growing at night? Diel patterns of growth, nitrogen content, herbivory, and chemical versus morphological defenses. Oecologia 75:233-245

Henry BE, Van Alstyne KL (2004) Effects of UV radiation on growth and phlorotannins in Fucus gardneri (Phaeophyceae) juveniles and embryos. J Phycol 40:527-533

Henry EC, Cole KM (1982) Ultrastructure of swarmers in the Laminariales (Phaeophyceae). I. Zoospores. J Phycol 18:550-569

Holm-Hansen O, Lubin D, Helbling EW (1993) Ultraviolet radiation and its effects on organisms in aquatic environments. In: Young AR et al (eds) Environmental UV photobiology. Plenum Press, New York, pp 379-425

Holzinger A, Lütz C, Karsten U, Wiencke C (2004) The effect of ujltraviolet radiation on ultrastructure and photosynthesis in the red macroalgae Palmaria palmata and Odonthalia dentata from Arctic waters. Plant Biol 6:568-577

Hoyer K, Karsten U, Wiencke C (2003) Inventory of UVabsorbing mycosporine-like amino acids in polar macroalgae and factors controlling their concentration. In: Huiskes AHL, Gieskes WWC, Rozema J, Schorno RML, Va der Vies SM, Wolff WJ (eds) Proceedings of the VIII SCAR meeting. Backhuys Publ Leiden, The Netherlands, pp 56-62

Hoyer K, Karsten U, Sawall T, Wiencke C (2001) Photoprotective substances in Antarctic macroalgae and their variation with respect to depth distribution, different tissues and developmental stages. Mar Ecol Prog Ser 211:117-129

Huovinen P, Gómez I, Lovengreen C (2006) A five-year study of solar ultraviolet radiation in southern Chile (39 S): potential impact on physiology of coastal marine algae? Photochem Photobiol 82:515-522

Huovinen P, Gómez I, Figueroa FL, Ulloa N, Morales V, Lovengreen C (2004) Ultraviolet-absorbing mycosporine-like amino acids in red macroalgae from Chile. Bot Mar 47:21-29
Huovinen PS, Oikari AOJ, Soimasuo MR, Cherr GN (2000) Impact of UV radiation on the early development of the giant kelp (Macrocystis pyrifera) gametophytes. Photochem Photobiol 72:308-313

Iwanzik W, Tevini M, Dohnt G, Voss M, Weiss W, Gräber O, Renger G (1983) Action of UV-B radiation on photosynthetic primary reactions in spinach chloroplasts. Physiol Plant 58:401-407

Jerlov NG (1976) Marine optics. Elsevier, Amsterdam

Johanson U, Gehrke C, Björn LO, Callaghan TV, Sonesson M (1995) The effects of enhanced UV-B radiation on a subarctic heath ecosystem. Ambio 24:106-111

Jordan BB, He J, Chow WS, Anderson JM (1992) Changes in mRNA levels and polypeptide subunits of ribulose1,5-bisphosphate carboxylase in response to supplementary ultraviolet-B radiation. Plant Cell Envir 15:91-98

Karban R, Agrawal AA, Thaler JS, Adler LS (1999) Induced plant responses and information content about risk of herbivory. Trend Ecol Evol 14: 443-447

Karban R, Nagasaka K (2004) Are defenses of wild radish populations well matched with variability and predictablity of herbivory? Evol Ecol 18:283-301

Karentz D (1989) Report on studies related to the ecological implications of ozone depletion on the Antarctic environment. Antarct J US 24:175-176

Karentz D, Cleaver JE, Mitchell D (1991b) Cell survival characteristics and molecular responses of Antarctic phytoplankton to ultraviolet-B radiation. J Phycol 27:326-341

Karentz D, McEuen FS, Land MC, Dunlap WC (1991a) Survey of mycosporine-like amino acid compounds in Antarctic organisms: potential protection from ultraviolet exposure. Mar Biol 108:157-166

Karsten U, Bischof K, Hanelt D, Tüg H, Wiencke C (1999) The effect of UV-radiation on photosynthesis and UV-absorbing substances in the endemic Arctic macroalga Devaleraea ramentacea (Rhodophyta). Physiol Plant 105:58-66

Karsten U, Friedl T, Schumann R, Hoyer K, Lembcke S (2005) Mycosporine-like amino acids (MAAs) and phylogenies in green algae: Prasiola and its relatives from the Trebouxiophyceae (Chlorophyta). J Phycol 41:557-566

Karsten U, Maier J, Garcia-Pichel F (1998b) Seasonality in UV-absorbing compounds of cyanobacterial mat communities from an intertidal mangrove flat. Aquat Microb Ecol 16:37-44

Karsten U, Sawall T, Hanelt D, Bischof K, Figueroa FL, Flores-Moya A, Wiencke C (1998a) An inventory of UV-absorbing mycosporine-like amino acids in macroalgae from polar to warm-temperate regions. Bot Mar 41:443-453

Kirk JTO (1994) Light and photosynthesis in aquatic ecosystems. Cambridge University Press, Cambridge

Klöser H, Quartino ML, Wiencke C (1996) Distribution of macroalgae and macroalgal communities in gradients of physical conditions in Potter Cove, King George Island, Antarctica. Hydrobiologia 333:1-17 
Korbee N, Huovinen P, Figueroa FL, Aguilera J, Karsten U (2005) Availability of ammonium influences photosynthesis and the accumulation of MAAs in two Porphyra species (Bangiales, Rhodophyta). Mar Biol 146:645-654

Kräbs G, Bischof K, Hanelt D, Karsten U, Wiencke C (2002) Wavelength-dependent induction of UVabsorbing mycosporine-like amino acids in the red alga Chondrus crispus. J Exp Mar Biol Ecol 268:69-82

Krause-Jensen D, McGlathery K, Rysgaard S, Christensen PB (1996) Production within dense mats of the filamentous macroalga Chaetomorpha linum in relation to light and nutrient availability. Mar Ecol Prog Ser 134:207-216

Lamb IM, Zimmermann MH (1977) Benthic marine algae of the Antarctic Peninsula. Antarctic Res Ser 23:129229

Langer J (1999) Messungen des arktischen stratosphärischen Ozons: Vergleich der Ozonmessungen in NyÅlesund, Spitzbergen 1997 und 1998. Ber Polarforsch 322:1-222

Larkum AWD, Wood WF (1993) The effect of UV-B radiation on photosynthesis and respiration of phytoplankton, benthic macroalgae and seagrasses. Photosyn Res 36:17-23

Lary DJ (1997) Catalytic destruction of stratospheric ozone. J Geophys Res 102:21515-21526

Lesser MP (1996) Acclimation of phytoplankton to UV-B radiation: oxidative stress and photoinhibition of photosynthesis are not prevented by UV-absorbing compounds in the dinoflagellate Prorocentrum micans. Mar Ecol Prog Ser 132:287-297

Lippert H, Iken K, Rachor E, Wiencke C (2001) Macrofauna associated with macroalgae in the Kongsfjord (Spitsbergen). Polar Biol 24:512-522

Lois R, Buchanan BBN (1994) Severe sensitivity to ulraviolet radiation in an Arabidopsis mutant deficient in flavonoid accumulation: II. Mechanisms of UV-resistance in Arabidopsis. Planta 194:504-509

Lorenz M, Schubert H, Forster RM (1997) In vitro- and in vivo-effects of ultraviolet-B radiation on the energy transfer in phycobilisomes. Photosynthetica 33:517-527

Long A, Michod RE (1995) Origin of sex for error repair. 1. Sex, diploidy, and haploidy. Theroret Pop Biol 47:18-55

Lotze HK, Worm B (2002) Complex interactions of climatic and ecological controls on macroalgal recruitment. Limnol Oceanogr 47:1734-1741

Lotze HK, Worm B, Molis M, Wahl M (2002) Effects of $\mathrm{UV}$ radiation and consumers on recruitment and succession of a marine macrobenthic community. Mar Ecol Prog Ser 243:57-66

Lubchenco J, Gaines SD (1981). A unified approach to marine plant-herbivore interactions. I. Poluations and communities. Annu Rev Syst 12:405-437

Lüning K (1990) Seaweeds. Their environment, biogeography, and ecophysiology. Wiley \& Sons Inc., New York, p 527

Macaya EC, Rothausler E, Thiel M, Molis M, Wahl M (2005) Induction of defenses and within-alga variation of palatability in two brown algae from the northern- central coast of Chile: effects of mesograzers and UV radiation. J Exp Mar Biol Ecol 325:214-227

Mackerness SAH, Jordan BR, Thomas B (1999) Reactive oxygen species in the regulation of photosynthetic genes by ultraviolet radiation (UV-B: $280-320 \mathrm{~nm}$ ) in green and etiolated buds of pea (Pisum sativum L). J Photochem Photobiol B Biol 48:180-188

Madronich S, McKenzie RL, Björn LO, Caldwell MM (1998) Changes in photobiologically active ultraviolet radiation reaching the earth's surface. J Photochem Photobiol B Biol 46:5-19

Maegawa M, Kunieda M, Kida W (1993) The influence of ultraviolet radiation on the photosynthetic activity of several red algae from different depths. Jpn J Phycol 41:207-214

Makarov M (1999) Influence of ultraviolet radiation on the growth of the dominant macroalgae of the Barents Sea. Chemosphere: Global Change Sci 1:461-467

Makarov MV, Voskoboinikov GM (2001) The influence of Ultraviolet-B radiation on spore release and growth of the kelp Laminaria saccharina. Bot Mar 44:89-94

Máté Z, Sass L, Szekeres M, Vass I, Nagy F (1998) UV-B induced differential transcription of psbA genes encoding the D1 protein of photosystem II in the cyanobacterium Synechocystis 6803. J Biol Chem 273:17439-17444

McMinn A, Ashworth C, Ryan K (1999) Growth and productivity of Antarctic sea ice algae under PAR and UV irradiances. Bot Mar 42:401-407

McNamara AE, Hill WR (1999) Effects of UV-B dose and irradiance: comparison among grazers. J North Am Benthol Soc 18:370-380

Mepsted R, Paul ND, Stephen J, Corlett JE, Nogués S, Jones NR, Ayres PG (1996) Effects of enhanced UV$\mathrm{B}$ radiation on pea (Pisum sativum L.) grown under field conditions in the UK. Global Change Biol 2:325334

Michler T, Aguilera J, Hanelt D, Bischof K, Wiencke C (2002) Long term effects of ultraviolet radiation on growth and photosynthetic performance of polar and cold-temperate marcoalgae. Mar Biol 140:1117-1127

Mitchell DL, Karentz D (1993) The induction and repair of DNA photodamage in the environment. In: Young AR, Björn LO, Moan J, Nultsch W (eds) Environmental UV photobiology. Plenum Press, New York, pp. 345-377

Molis M, Körner J, Ko YW, Kim JH, Wahl M (2006) Inducible responses in the brown seaweed Ecklonia cava: the role of grazer identity and season. J Ecol 94:243-249

Molis M, Lenz M, Wahl M (2003) Radiation effects along a UV-B gradient on species composition and diversity of a shallow-water macrobenthic community in the western Baltic. Mar Ecol Prog Ser 263:113-125

Molis M, Wahl M (2004) Transient effects of solar ultraviolet radiation on the diversity and structure of a field-grown epibenthic community at Luderitz, Namibia. J Exp Mar Biol Ecol 302:51-62

Müller DG (1977) Sexual reproduction in British Ectocarpus siliculosus. Br Phycol J 12:131-136 
Murphy TM (1983) Membranes as targets of ultraviolet radiation. Physiol Plant 58:381-388

Nogués S, Baker NR (1995) Evaluation of the role of damage to photosystem II in the inhibition of $\mathrm{CO}_{2}$ assimilation in pea leaves on exposure to UV-B radiation. Plant Cell Envir 18:781-787

Norton TA (1992) Dispersal by macroalgae. Br Phycol J 27:293-301

Okuda T, Neushul M (1981) Sedimentation studies of red algal spores. J Phycol 17:113-118

Pang S, Gómez I, Lüning K (2001) The red macroalga Delesseria sanguinea as a UVB-sensitive model organism: selective growth reduction by UVB in outdoor experiments and rapid recording of growth rate during and after pulses. Eur J Phycol 36:297-216

Pavia H, Brock E (2000) Extrinsic factors influencing phlorotannin production in the brown alga Ascophyllum nodosum. Mar Ecol Prog Ser 193:285-294

Pavia H, Cervin G, Lindgren A, Aberg P (1997) Effects of UV-B radiation and simulated herbivory on phlorotannins in the brown alga Ascophyllum nodosum. Mar Ecol Prog Ser 157:139-146

Pavia H, Toth GB (2000) Inducible chemical resistance to herbivory in the brown seaweed Ascophyllum nodosum. Ecology 81:3212-3225

Pérez-Rodriguez E (2000) Caracterización bio-optica de aguas oceánicas y costeras. Fotosíntesis, fotoinhibición y fotoprotección bajo radiación ultravioleta y fotosintética en macrofitos marinos. PhD Thesis, Universidad de Málaga, p 356

Poppe F, Hanelt D, Wiencke C (2002) Changes in ultrastructure, photosynthetic activity and pigments in the Antarctic red alga Palmaria decipiens during acclimation to UV radiation. Bot Mar 45:253-261

Poppe F, Schmidt RAM, Hanelt D, Wiencke C (2003) Effects of UV radiation on the ultrastructure of several red algae. Phycol Res 51:11-19

Post A, Larkum AW (1993) UV-absorbing pigments, photosynthesis and UV exposure in Antarctica: comparison of terrestrial and marine algae. Aquat Bot 45:231-243

Ragan MA, Glombitza KW (1986) Phlorotannins, brown algal polyphenols. In: Round FE, Chapman DJ (eds) Progress in phycolocical research 4. Biopress Ltd, Bristol, pp 129-241

Reed DC, Brezezinski MA, Coury DA, Graham WM, Petty RL (1999) Neutral lipids in macroalgal spores and their role in swimming. Mar Biol 133:737-479

Renger G, Voss M, Gräber P, Schulze A (1986) Effect of UV irradiation on differential partial reactions of the primary processes of photosynthesis. In: Worrest RC, Caldwell MM (eds) Stratospheric ozone reduction, solar ultraviolet radiation and plant life. NATO ASI Series, vol G8. Springer, Heidelberg, pp. 171-184

Roleda MY (2006) Effects of ultraviolet radiation on early life stages of cold temperate and Arctic macroalgae: implications for recruitment and vertical depth distribution. Ber Polar Meeresforsch 526:1-176

Roleda MY, Clayton MN, Wiencke C (2006c) Screening capacity of UV-absorbing compounds in spores of Arctic Laminariales. J Exper Mar Biol Ecol (subm.)
Roleda MY, Hanelt D, Wiencke C (2005b) Growth kinetics related to physiological parameters in young Saccorhiza dermatodea and Alaria esculenta sporophytes exposed to UV radiation. Pol Biol 28:466-479

Roleda MY, Hanelt D, Wiencke C (2006b) Growth and DNA damage in young Laminaria sporophytes exposed to ultraviolet radiation: implication for depth zonation of kelps on Helgoland (North Sea). Mar Biol 148:1201-1211

Roleda MY, Hanelt D, Wiencke C (2006d) Exposure to ultraviolet radiation delays photosynthetic recovery in Arctic kelp zoospores, Photosynth Res DOI 10.1007/ s11120-006-9055-y

Roleda MY, van de Poll WH, Hanelt D, Wiencke C (2004) PAR and UVBR effects on photosynthesis, viability growth and DNA in different life stages of two coexisting Gigartinales: implications for recruitment and zonation pattern. Mar Ecol Progr Ser 281:37-50

Roleda MY, Wiencke C, Hanelt D (2006a) Thallus morphology and optical characteristics affect growth and DNA damage by UV radiation in juvenile Arctic Laminaria sporophytes, Planta 223:407-417

Roleda MY, Wiencke C, Hanelt D, van de Poll WH, Gruber A (2005a) Sensitivity of Laminariales zoospores from Helgoland (North Sea) to ultraviolet and photosynthetically active radiation: implications for depth distribution and seasonal reproduction. Plant Cell Environ 28:466-479

Santas R, Korda A, Lianou C, Santas P (1998) Community response to UV radiation. I. Enhanced UVB effects on biomass and community structure of filamentous algal assemblages growing in a coral reef mesocosm. Mar Biol 131:153-162

Scharf ER, Gerhard JC (1983) Axis determination in eggs of Xenopus laevis: a critical period before first cleavage. Identified by the common effects of cold, pressure and untraviolet radiation. Developm Biol 99:75-87

Schmitt TM, Hay ME, Lindquist N (1995) Constraints on chemically mediated coevolution: multiple functions for seaweed secondary metabolites. Ecology 76:107-123

Schoenwaelder MAE, Wiencke C, Clayton MN, Glombitza KW (2003) The effect of elevated UV radiation on Fucus spp. (Fucales, Phaeophyta) zygote and embryo development. Plant Biol 5:366-377

Schoenwaelder MEA, Clayton MN (1999) The role of the cytoskeleton in brown algal physode movement. Eur J Phycol 34:223-229

Schoenwaelder MEA, Wiencke C (2000) Phenolic compounds in the embryo development of several northern hemisphere fucoids. Plant Biol 2:24-33

Schoenwaelder MEA (2002a) Physode distribution and the effects of 'Thallus Sunburn' in Hormosira banksii (Fucales, Phaeophyceae). Bot Mar 45:262-266

Schoenwaelder MEA (2002b) The occurence and cellular significance of physodes in brown algae. Phycologia 41:125-139

Schoembeck M, Norton TA (1978) Factors controlling the upper limits of fucoid algae on the shore. J Exp Mar Biol Ecol 31:303-313

Sotka EE, Taylor RB, Hay ME (2002) Tissue-specific induction of resistance to herbivores in a brown sea- 
weed: the importance of direct grazing versus waterborne signals from grazed neighbors. J Exp Mar Biol Ecol 277:1-12

Sousa WP, Connell JH (1992) Grazing and succession in marine algae. In: John DM, Hawkins S, Price JH (eds) Plant-animal interactions in the marine benthos. Clarendon Press, Oxford, pp 425-441

Stephenson TA, Stephenson A (1972) Life between tidemarks on rocky shores. Freeman, San Francisco, p 425

Strahle S, Jesuthasan U (1993) Ultraviolet irradiation impairs epiboly in zebrafish embryos: evidence for a microtubule-dependent mechanism of epiboly. Development 119:909-919

Strid A, Chow WS, Anderson JM (1990) Effects of supplementary ultraviolet-B radiation on photosynthesis in Pisum sativum. Biochim Biophys Acta 1020:260-268

Svendsen H, Beszczynska-Møller A, Lefauconnier B, Tverberg V, Gerland S, Hagen JO, Ørbæk JB, Bischof K, Papucci C, Zajaczkowski M, Azzolini R, Bruland O, Wiencke C, Winther JG, Hodson A, Mumford P (2002) The physical environment of KongsfjordenKrossfjorden-an Arctic fjord system in Svalbard. Pol Res 21:133-166

Swanson AK, Druehl LD (2000) Differential meiospore size and tolerance of ultraviolet light stress within and among kelp species along a depth gradient. Mar Biol 136:657-664

Swanson AK, Druehl LD (2002) Induction, exudation and the UV protective role of kelp phlorotannins. Aquat Bot 73:241-253

Taylor RB, Sotka E, Hay ME (2002) Tissue-specific induction of herbivore resistance: seaweed response to amphipod grazing. Oecologia 132:68-76

Teramura AH (1983) Effects of ultraviolet-B radiation on the growth and yield of crop plants. Physiol Plant 58:415-427

Tevini M, Teramura AH (1989) UV-B effects in terrestrial plants. Photochem Photobiol 50:479-487

Thiel M, Gutow L (2005) The ecology of rafting in the marine environment. II. The rafting organisms and community. Oceanogr Mar Biol - Ann Rev 43:279-418

Thomas D (2002) Seaweeds. The natural Hostory Museum London, Smithsonian Institution Press, p 96

van de Poll WH, Eggert A, Buma AGJ, Breeman AM (2001) Effects of UV-B-induced DNA damage and photoinhibition on growth of temperate marine red macrophytes: habitat-related differences in UV-B tolerance. J Phycol 37:30-37

van de Poll WH, Hanelt D, Hoyer K, Buma AGJ, Breeman AM (2002) Ultraviolet-B-induced cyclobutane-pyrimidine dimer formation and repair in arctic marine macrophytes. Photochem Photobiol 76:493-500

Vass I (1997) Adverse effects of UV-B light on the structure and function of the photosynthetic apparatus. In: Pessarakli M (ed) Handbook of photosynthesis. Marcel Dekker Inc., New York, pp 931-949

Véliz K, Edding M, Tala F, Gómez I (2006) Effects of ultraviolet radiation on different life cycle stages of the Pacific kelps, Lessonia nigrescens and Lessonia trabeculata (Laminariales, Phaeophyceae). Mar Biol DOI 10.1007/s00227-006-0301-9

Vergara JJ, Pérez-Lloréns JL, Peralta G, Hernández I (1997) Seasonal variation of photosynthetic performance and light attenuation in Ulva canopies from Palmones river estuary. J Phycol 33:773-779

Vincent WF, Belzile C (2003) Biological UV exposure in the polar oceans: Arctic-Antarctic comparisions. In: Huiskes AHL et al (eds) Antarctic biology in a global context. Backhuys Publishers, Leiden Netherland, pp 176-181

Vinebrooke RD, Leavitt PR (1999) Differential responses of littoral communities to ultraviolet radiation in an alpine lake. Ecology 80:223-237

Wahl M (2001) Small scale variability of benthic assemblages: biogenic neighbourhood effects. J Exp Mar Biol Ecol 258:101-114

Wahl M, Hay ME (1995) Associational resistance and shared doom: effects of epibiosis on herbivory. Oecologia 102:329-340

Wahl M, Molis M, Davis A, Dobretsov S, Durr ST, Johansson J, Kinley J, Kirugara D, Langer M, Lotze HK, Thiel M, Thomason JC, Worm B, Ben-Yosef DZ (2004) UV effects that come and go: a global comparison of marine benthic community level impacts. Global Change Biol 10:1962-1972

Wiencke C, Clayton MN (2002) Antarctic seaweeds. Synopses of the Antarctic benthos, vol 9. A.R.G. Gantner Verlag KG, Ruggell, p 239

Wiencke C, Clayton MN, Schoenwaelder M (2004a) Sensitivity and acclimation to UV radiation of zoospores from five species of Laminariales from the Arctic. Mar Biol 145:31-39S

Wiencke C, Gómez I, Pakker H, Flores-Moya A, Altamirano M, Hanelt D, Bischof K, Figueroa FL (2000) Impact of UV-radiation on viability, photosynthetic characteristics and DNA on brown algal zoospores: implications for depth zonation. Mar Ecol Progr Ser 197:217-229

Wiencke C, Roleda MY, Gruber A, Clayton M, Bischof K (2006) Susceptibility of zoospores to UV radiation determines upper depth distribution limit of Arctic kelps: evidence through field experiments. J Ecol 94:455-463

Wiencke C, Vögele B, Kovaltchouk NA, Hop H (2004b) Species composition and zonation of marine benthic macroalgae at Hansneset in Kongsfjorden, Svalbard. Ber Polar Meeresforsch 492:55-62

Worm B, Duffy JE (2003) Biodiversity, productivity and stability in real food webs. Trend Ecol Evol 18:628-632

Worrest RC (1983) Impact of solar ultraviolet-B radiation (290-320 nm) upon marine microalgae. Physiol Plant 58:428-434

Yakovleva IM, Dring MJ, Titlyanov EA (1998) Tolerance of North Sea algae to UV and visible radiation. Russ J Plant Physiol 45:45-54

Zielinski K (1990) Bottom macroalgae of the Admirality Bay (King George Island, South Shetlands, Antarctica). Pol Polar Res 11:95-131 